\title{
Runx3 is required for the specification of TrkC-expressing mechanoreceptive trigeminal ganglion neurons
}

\author{
Kouji Senzaki ${ }^{1}$, Shigeru Ozaki ${ }^{1}$, Masaaki Yoshikawa ${ }^{1}$, \\ Yoshiaki Ito ${ }^{2}$, Takashi Shiga ${ }^{1}$ *
}

${ }^{1}$ Graduate School of Comprehensive Human Sciences, University of Tsukuba, 1-1-1 Tennodai, Tsukuba, Ibaraki 305-8577, Japan.

${ }^{2}$ Institute of Molecular and Cell Biology, 61 Biopolis Drive, Proteos, Singapore 138673, Singapore.

*Corresponding author (e-mail: tshiga@md.tsukuba.ac.jp)

\section{Word count}

Abstract $<150$ words

Keywords: Runx3; Transcription factor; Trigeminal ganglion; TrkB; TrkC; Merkel endings; Mechanoreceptive neurons; Cell fate specification; Axon projection 


\begin{abstract}
Sensory neurons project axons to specific peripheral and central targets according to their sensory modality. Runx3 is crucially involved in proprioceptive dorsal root ganglion neuron development. Runx3 is also expressed in trigeminal ganglion (TG) neurons. The role of Runx3 in the TG, however, is largely unknown, because the TG does not contain proprioceptive neurons. In Runx3-deficient $\left(\operatorname{Runx}^{-/}\right)$mice, TrkB-expressing TG neurons were increased, whereas TrkC-expressing TG

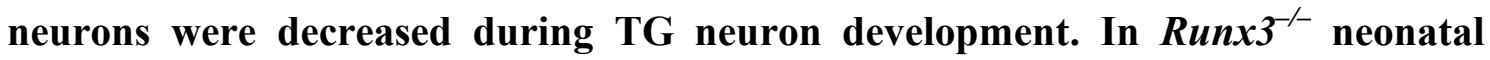
mice, TrkC-expressing TG neurons did not project to the Merkel cells in the outer root sheath (ORS) of whisker vibrissae peripherally and the spinal trigeminal nucleus pars interpolaris (Sp5I) centrally. These findings suggest that Runx3 is required for the specification of TrkC-expressing TG neurons, conveying mechanoreceptive signals from the Merkel cells in the ORS of the whisker vibrissae to the Sp5I.
\end{abstract}




\section{Introduction}

The mammalian Runt-related (Runx) transcription factor family comprises three members: Runx1, 2, and 3. These Runxs play important roles in developmental processes of various cell types, including hematopoietic cells, osteoblasts, and gastric epithelial cells (for reviews, see Coffman, 2003; Ito, 2004; 2008). Runx1 and Runx3 are also expressed in neuronal subtypes in the central and peripheral nervous systems (Simeone et al., 1995; Theriault et al., 2004; Theriault et al., 2005). In the dorsal root ganglion (DRG), Runx1 and Runx3 are expressed in a subpopulation of neurons. Runx1 controls the cell fate specification and the axonal projections of nociceptive neurons, which convey information about pain, whereas Runx 3 controls those of proprioceptive neurons, which convey information regarding muscle length and tension (for reviews, see Inoue et al., 2008, Marmigère and Ernfors, 2007). Furthermore, Runx1 and Runx3 may be involved in the development of proprioceptive and nociceptive DRG neurons, respectively (Yoshikawa et al., 2007; Nakamura et al., 2008). Runx1 and Runx3 are also expressed in a subpopulation of trigeminal ganglion (TG) neurons, but their roles are not known (Levanon et al., 2002; Theriault et al., 2004).

General somatosensory information is conveyed to the central nervous system at spinal levels through the DRG and at cranial levels through the TG. Although these ganglia have a similar function, they have distinct developmental origins. The DRG contains neurons originating from neural crest cells, whereas the TG contains neurons originating from neural crest cells and placodal ectoderm cells (Baker and Bronner-Fraser, 2001; Chan and Tam, 1988). Moreover, the DRG has nociceptive, mechanoreceptive, and proprioceptive neurons, whereas the TG has nociceptive and mechanoreceptive neurons. The proprioceptive neurons of the trigeminal system are located in the mesencephalic trigeminal nucleus in the brainstem (Lazarov, 2002). Though this does not mean that the proprioceptive neurons do not exist in the TG, no studies have shown proprioceptive neurons in the TG. In the developing DRG, Runx3 is necessary for the acquisition of proprioceptive neuron identities (Inoue et al., 2002; Levanon et al., 2002; Nakamura et al., 2008). The role of Runx3 in the developing TG, which lacks proprioceptive neurons, however, is largely unknown.

In the present study, to elucidate the role of Runx3 in the development of TG neurons, we analyzed cell fate and axonal projections of TG neurons of Runx3-deficient $\left(\right.$ Run $\left.x 3^{--}\right)$mice at the embryonic and neonatal stages. 


\section{Results}

Changes of the expression of marker molecules in TG neurons of neonatal Runx $^{-/-}$ mice Because Runx $3^{-/-}$mice die soon after birth (Inoue et al., 2002), we first analyzed the TG of Runx $3^{+/+}$and Runx $3^{-/-}$mice at postnatal day (P) 0 . We examined whether the loss of Runx 3 affects the number of TG neurons using NeuN as a pan-neuronal marker. The number of NeuN-expressing $\left(\mathrm{NeuN}^{+}\right)$neurons in the TG was not different between Run $x 3^{+/+}$and Runx $3^{-/-}$mice (Figs. 1A'-A'"'), suggesting that Runx3-deficiency does not affect the total number of TG neurons.

To clarify the role of Runx3 in the cell fate of TG neurons, we examined the number of neurons expressing the neurotrophin receptor family members TrkA, TrkB, and TrkC

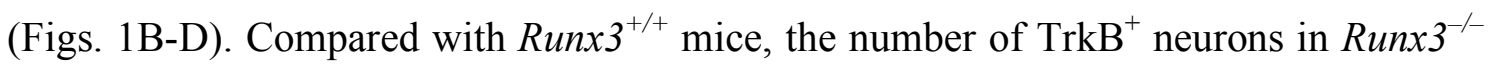
mice increased to $143 \%$ (Fig. 1C', , Runx $3^{+/+}, 14475 \pm 378$; Runx $3^{-/}, 20653 \pm 676$; $p<0.0001$ ), while that of $\operatorname{TrkC}^{+}$neurons decreased to 38\% (Fig. 1D',', 10605 \pm 714 ; $4075 \pm 528 ; p<0.001)$. The number of TrkA ${ }^{+}$neurons was not different in Runx $3^{-/-}$mice (Fig. 1B',').

To gain further insight into the role of Runx3 in TG neuron subtype specification, we examined the number of neurons that express calcium binding proteins ( $\mathrm{PV}$, Calr and $\mathrm{CB}$ ) and neuropeptides (SOM, CGRP and SubP). A similar number of $\mathrm{PV}^{+}$neurons was observed in the TG of Runx $3^{+/+}(2810 \pm 164)$ and $R u n x 3^{-/-}(2794 \pm 114)$ mice (Fig. $1 \mathrm{E}^{\prime \prime}$ '), which is in great contrast to the lack of $\mathrm{PV}^{+}$neurons observed in $R u n \times 3^{-/}$DRG (Nakamura et al., 2008). Compared with Runx ${ }^{+/+}$mice, $\mathrm{SOM}^{+} \mathrm{TG}$ neurons were dramatically decreased to $16 \%$ in $R u n x 3^{-/}$mice (Fig. 1F' ', 395 $\pm 50 ; 63 \pm 24 ; p<0.001$ ), suggesting that SOM expression is downregulated in the absence of Runx3. The numbers of $\mathrm{Calr}^{+}, \mathrm{CB}^{+}, \mathrm{CGRP}^{+}$, and $\mathrm{SubP}^{+} \mathrm{TG}$ neurons were not different between Run $x 3^{+/+}$and Runx $3^{-/-}$mice (Fig. S1). These findings suggest that Runx3 negatively regulates the expression of TrkB and positively regulates the expression of $\operatorname{TrkC}$ and SOM in the TG at P0.

\section{Correlation between the expression of Runx3 and marker molecules at the neonatal stage}

$\mathrm{TrkB}^{+}$neurons were increased and $\mathrm{TrkC}^{+}$neurons decreased in Runx $3^{-/-}$TG at P0 (Fig. 1). We next examined the expression of $\operatorname{TrkB}, \operatorname{TrkC}$ and Runx3 by triple immunostaining in order to clarify the correlation between the expression of TrkB and TrkC, and the involvement of Runx 3 in the regulation of these expressions in the TG. Runx3 was expressed in a subpopulation of $\operatorname{TrkB}^{+} / \operatorname{TrkC}^{-}$neurons, $\operatorname{TrkB}^{-} / \operatorname{TrkC}^{+}$neurons,

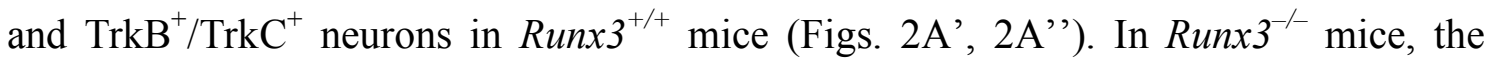


number of $\operatorname{TrkB}^{-} / \operatorname{TrkC}^{+}$neurons was decreased (Fig. 2G, Runx $3^{+/+}, 6643 \pm 593$; Runx $3^{-/-}$, $2249 \pm 345 ; p<0.001$ ) and that of $\operatorname{TrkB}^{+} / \operatorname{TrkC}^{-}$neurons was increased (Fig. 2G, $13952 \pm 524 ; 16293 \pm 671 ; p<0.05)$ compared with that in $R u n x 3^{+/+}$mice. The number of $\operatorname{TrkB}^{+} / \operatorname{TrkC}^{+}$neurons, however, was not significantly different between these mice $(3055 \pm 509 ; 3649 \pm 455$; Figs. 2A', 2B', 2G). These findings suggest that Runx3 promotes the cell type specification of $\operatorname{TrkB}^{-} / \operatorname{TrkC}^{+}$neurons, and suppresses the cell type specification of $\mathrm{TrkB}^{+} / \mathrm{TrkC}^{-}$neurons in the TG.

We also examined the relationship of the co-expression of SOM or PV with Runx3 and TrkC to elucidate the role of Runx3 in the expression of SOM and PV. In Runx $3^{+/+}$ mice, TrkC and Runx3 were expressed in approximately $82 \%$ and $76 \%$ of $\mathrm{SOM}^{+}$ neurons, respectively (Figs. 2C', 2H). In $R u n x 3^{+/+}$mice, approximately 280 neurons co-expressed SOM and Runx3 (278 \pm 49$)$. The reduced number of $\mathrm{SOM}^{+}$neurons (281 \pm 42 ) in Runx $3^{-/-}$TG was comparable to the number of Runx $3^{+} / \mathrm{SOM}^{+}$neurons (Figs. $2 \mathrm{C}$ ', $2 \mathrm{D}$ ', $2 \mathrm{H}$ ). Taken together, these findings suggest that most $\mathrm{SOM}^{+} \mathrm{TG}$ neurons co-express TrkC and Runx3, and Runx3 may positively regulates the expression of SOM cell-autonomously.

TrkC was expressed in approximately $69 \%$ of $\mathrm{PV}^{+}$neurons, but Runx3 was expressed in only $9 \%$ of $\mathrm{PV}^{+}$neurons (Figs. 2E', 2I). In addition, the number of $\mathrm{PV}^{+} / \mathrm{TrkC}^{+}$neurons was not significantly different between Runx $3^{+/+}(1705 \pm 252)$ and Run $3^{-/-}(1572 \pm 174)$ mice. In the DRG, most $\mathrm{PV}^{+}$neurons co-express TrkC and Runx3 in Runx $3^{+/+}$mice, and PV is not expressed in Runx $3^{-/-}$mice (Nakamura et al., 2008). These findings suggest that Runx3 is not involved in the expression of PV in the TG, although the majority of $\mathrm{PV}^{+}$neurons co-express TrkC, like in the DRG.

\section{Runx3 controls TrkB and TrkC expression from the early stage of TG neuron development}

To determine the embryonic stage at which Runx3 begins to control the expression of TrkB and TrkC, we estimated the number of $\operatorname{TrkB}^{+}$and $\operatorname{TrkC}^{+}$neurons from E10.5 to E13.5 (Fig. 3). Similar numbers of $\operatorname{TrkB}^{+}\left(\right.$Runx $\left.3^{+/+}, 1982 \pm 99 ; R u n x 3^{-/-}, 1683 \pm 39\right)$ and $\operatorname{TrkC}^{+}(4443 \pm 88 ; 4226 \pm 12)$ neurons were observed in $R u n x 3^{+/+}$and $R u n x 3^{-/}$mice at E10.5 (Figs. 3A'-3D'). Compared with $R u n x 3^{+/+}$mice, in $R u n x 3^{-/-}$mice, the number of $\mathrm{TrkB}^{+}$neurons was increased to $164 \%(8386 \pm 534 ; 13775 \pm 979 ; p<0.01), \quad 145 \%$ $(4424 \pm 236 ; 6436 \pm 616 ; p<0.05)$, and $164 \%(5371 \pm 599 ; 8810 \pm 668 ; p<0.01)$ at E11.5, E12.5, and E13.5, respectively (Figs. 3A'"-3A',', 3B' '-3B',', 3E), whereas that of $\mathrm{TrkC}^{+}$neurons was decreased to $56 \%(8582 \pm 88 ; 4808 \pm 237 ; p<0.01), 70 \%(5856 \pm 357$; $4095 \pm 485 ; p<0.05)$, and $39 \%(6479 \pm 368 ; 2548 \pm 195 ; p<0.001)$ at E11.5, E12.5, and 
E13.5, respectively (Figs. 3C'"-3C',', 3D' '-3D',', 3F). We also examined TrkA ${ }^{+}$and $\mathrm{NeuN}^{+}$neurons at E11.5 and E13.5. The number of $\operatorname{TrkA}^{+}$neurons was not different between $R u n x 3^{+/+}$and Run $x 3^{-/-}$mice at either embryonic stage. The number of $\mathrm{NeuN}^{+}$

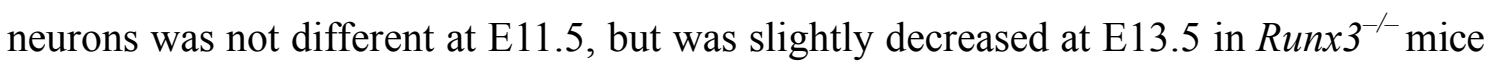
(Fig. S2). These results suggest that Runx3 may begin to control the expression of TrkB and TrkC in TG neurons at E11.5.

We then investigated the co-expression of TrkB, TrkC, and Runx3 in the TG at E10.5 and E13.5 (Fig. 4). At E10.5, Runx3, together with TrkB and TrkC, appeared in the TG of Run $x 3^{+/+}$mice. Most of the $\operatorname{TrkB}^{+}$neurons $(91 \%)$ expressed TrkC in both Run $x 3^{+/+}$and Run $x 3^{-/-}$TG (Figs. 4A', 4C', 4E), and most of the $\operatorname{TrkB}^{+} / \operatorname{TrkC}^{+}$neurons (88\%) expressed Runx3 in Runx $3^{+/+}$TG (Figs. 4A', 4E). The numbers of $\operatorname{TrkB}^{-} / \operatorname{TrkC}^{+}$ $(2809 \pm 407 ; 2701 \pm 37), \operatorname{TrkB}^{+} / \operatorname{TrkC}^{-}(173 \pm 26 ; 159 \pm 64)$, and $\operatorname{TrkB}^{+} / \operatorname{TrkC}^{+}(1719 \pm 96$; $1623 \pm 136)$ neurons were not different between $R u n \times 3^{+/+}$and $R u n x 3^{-/-}$mice at E10.5, suggesting that Runx3 is not involved in regulating the expression of $\operatorname{TrkB}$ and $\operatorname{TrkC}$ at E10.5, despite the fact that Runx3 was expressed in the majority of $\operatorname{TrkB}^{+} / \operatorname{TrkC}^{+}$ neurons (Fig. 4E).

At E13.5, TrkC was expressed in few $\operatorname{TrkB}^{+}$neurons $(1.3 \%)$ in Runx $3^{+/+}$mice. In Run $x 3^{+/+}$mice, virtually all $\operatorname{TrkC}^{+}$neurons $(92 \%)$ and only a few $\operatorname{TrkB}{ }^{+}$neurons $(3.7 \%)$ expressed Runx3 (Figs. 4B', 4F). In sharp contrast to Runx $3^{+/+}$mice, TrkC was expressed in most $\operatorname{TrkB}^{+}$neurons (91\%) in $R u n \times 3^{-/}$mice, and the number of $\operatorname{TrkB}^{+} / \operatorname{TrkC}^{+}$neurons increased by 35 -fold $(97 \pm 3 ; 3436 \pm 71 ; p<0.001$, Figs. 4B', 4D', $4 \mathrm{~F})$. In addition, the number of $\operatorname{TrkB}^{-} / \operatorname{TrkC}^{+}$neurons was decreased to $4.9 \%(7001 \pm 180$; $341 \pm 7 ; p<0.001$ ), whereas that of $\mathrm{TrkB}^{+} / \mathrm{TrkC}^{-}$neurons was not significantly different between $\operatorname{Runx}^{+/+}(5491 \pm 76)$ and $\operatorname{Runx}^{-/-}(5146 \pm 428)$ mice at E13.5 (Figs. 4B', 4D', $4 \mathrm{~F})$.

These findings suggest that Runx 3 positively regulates the expression of TrkC and negatively regulates the expression of $\operatorname{TrkB}$ in a cell-autonomous manner, and that Runx3 has a role in specifying $\operatorname{TrkB} / \operatorname{TrkC}$ co-expressing $\mathrm{TG}$ neurons as single-expressing TrkB or TrkC TG neurons.

\section{Axonal projection of TrkB ${ }^{+}$and TrkC ${ }^{+}$TG neurons in $\operatorname{Runx} 3^{-/-}$mice}

We next analyzed the axonal projections of TG neurons at E13.5 and P0. At E13.5, in Run $x 3^{+/+}$mice, TG afferents reached the peripheral and central targets (Figs. 5, 6). In the peripheral projection of TG neurons of E13.5 Run $\times 3^{+/+}$mice, $\operatorname{TrkB}^{+}$and $\mathrm{TrkC}^{+}$ afferents innervated the facial areas, including the large and small whisker vibrissae (Figs. 5A, 5C, 5E). In Run $x 3^{-/-}$mice, TrkB ${ }^{+}$afferents projected to these areas, but few 
$\operatorname{TrkC}^{+}$afferents were observed (Figs. 5B, 5D, 5F), despite the fact that a substantial number of TG neurons expressed TrkC (Figs. 3D',,', 3F). In the central projection, in Run $x 3^{+/+}$mice, $\mathrm{TrkB}^{+}$and $\mathrm{TrkC}^{+}$afferents projected to the medial and lateral portion of the spinal trigeminal tract $(\mathrm{Sp} 5 \mathrm{t})$, respectively, in the metencephalon and

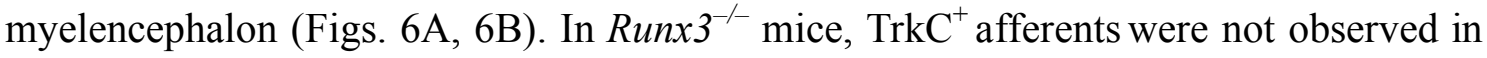
the metencephalon and myelencephalon (Figs. 6C, 6D), and $\operatorname{TrkB}^{+}$afferents were observed in the lateral portion of the $\mathrm{Sp} 5 \mathrm{t}$ as well as the medial portion where $\mathrm{TrkC}^{+}$ afferents projected in Run $x 3^{+/+}$mice (arrows in Figs. 6D"', 6D",'). Considering that most of the $\operatorname{TrkC}^{+}$TG neurons co-express TrkB in Runx $3^{-/-}$mice at E13.5 (Figs. 4D', 4D', 4F), these findings suggest that $\operatorname{TrkB}^{+} / \operatorname{TrkC}^{+}$neurons (yellow in Figs. 4D', 4D', $4 \mathrm{~F}$ ) failed to project to the peripheral and central targets and $\operatorname{TrkB}^{+} / \operatorname{TrkC}^{-}$neurons (green in Figs. 4D', 4D', 4F, 6D) projected to an aberrant central target in the lateral portion of the Sp5t in Run $\times 3^{-/-}$mice.

In $R u n \times 3^{-/-} \mathrm{TG}$, most of the $\mathrm{TrkC}^{+}$neurons co-expressed TrkB at E13.5, while approximately $60 \%$ of $\operatorname{TrkC}^{+}$neurons co-expressed TrkB at P0 (Figs. 2F', 4D'). To clarify the identities of the $\operatorname{TrkB}^{+} / \operatorname{TrkC}^{+}$and $\operatorname{TrkB}^{-} / \operatorname{TrkC}^{+}$neurons, we investigated $\operatorname{TrkB}^{+}$and $\operatorname{TrkC}^{+}$afferents at P0 (Fig. 7). TrkC ${ }^{+}$afferents projected to the Merkel cells in the outer root sheath (ORS) of the large and small whisker vibrissae in Runx $3^{+/+}$mice (Fig. 7A, arrows in Figs. 7B, 7G; Fünfschilling et al., 2004), but not in $R u n \times 3^{-/-}$mice (Figs. 7D, 7E, 7H), while $\operatorname{TrkB}^{+}$and $\operatorname{TrkC}^{+}$afferents projecting to the reticular ending of the large whisker vibrissae were observed in both $R u n \times 3^{+/+}$and $R u n \times 3^{-/-}$mice (Figs. 7C, 7F). Some $\operatorname{TrkC}^{+}$fibers that co-express TrkA, a thermo-nociceptive marker, were observed in Runx $3^{+/+}$mice, and similar fibers were also observed in $R u n \times 3^{-/-}$mice (arrowheads in Figs. 7G, 7H). In the brainstem, $\operatorname{TrkC}^{+}$afferents projected to the spinal trigeminal nucleus pars interpolaris (Sp5I) and caudalis $(\mathrm{Sp} 5 \mathrm{C})$ in $R u n \times 3^{+/+}$mice, whereas $\mathrm{TrkC}^{+}$afferents projected to Sp5C, but not to the Sp5I in Runx $3^{-/}$mice (Fig. 8). $\mathrm{TrkB}^{+}$afferents mainly projected to the Sp5I in $R u n \times 3^{+/+}$mice, and similar TrkB ${ }^{+}$ afferents were observed in the Sp5I of Run $x 3^{-/-}$mice (Fig. 8).

Some $\operatorname{TrkC}^{+}$afferents were lost in the peripheral and central targets and $\mathrm{TrkC}^{+}$ neurons were decreased in Runx $3^{-/-}$mice. Therefore, we examined whether apoptosis of TG neurons contributed to these phenotypes. The number of active caspase $3^{+}$apoptotic cells was not changed in Runx $3^{+/+}$and Runx $3^{-/-}$mice from E11.5 to P0 (Fig. S3). In addition, because apoptosis is eliminated in $\mathrm{Bax}^{-/}$TG (White et al., 1998), we examined the TrkC expression in the TG neurons and the $\operatorname{TrkC}^{+}$afferents in the central target of Run $3^{-/} / \mathrm{Bax}^{-/}$double-knockout and $\mathrm{Runx}^{+/+} / \mathrm{Bax}^{-/-}$control mice at E13.5. TrkC expression in the $\mathrm{TG}$ and the central projection of $\operatorname{TrkC}^{+} \mathrm{TG}$ neurons in 
Runx $3^{-/-} / \mathrm{Bax}^{-/-}$and $\operatorname{Runx}^{+/+} / \mathrm{Bax}^{-/-}$mice were similar to that in $\operatorname{Run} \times 3^{-/-}$and $R u n x 3^{+/+}$ mice, respectively (Figs. 6E-J). These results strongly suggest that Runx3 inactivation did not induce caspase3-dependent apoptosis, and that the reduction of $\operatorname{TrkC}^{+}$neurons and the loss of TrkC afferents were not due to apoptosis.

Finally, we examined the overall TG projections by injecting DiI crystals into TG in Run $x 3^{+/+}$and Runx $3^{-/-}$mice at E13.5, E16.5, and P0. DiI-labeled afferents projected to Sp5t at E13.5, and Sp5I at E16.5 and P0 in both Runx $3^{+/+}$and Runx $3^{-/-}$mice. These projections, however, seemed smaller in $\operatorname{Run} x 3^{-/-}$mice than those in $R u n x 3^{+/+}$mice (Fig. S4).

In summary, both $\operatorname{TrkC}^{+}$afferents and $\operatorname{TrkC}^{+} / \operatorname{TrkB}^{+}$afferents projecting to the whisker and the lateral portion of $\mathrm{Sp} 5 \mathrm{t}$ were lost in $R u n x 3^{-/-}$mice at E13.5. TrkC afferents projecting to Merkel cells in the ORS of whisker vibrissae and the Sp5I were also lost in $\mathrm{Runx}^{-/-}$mice at P0. Therefore, Runx3 is suggested to control the specification of $\operatorname{TrkC}^{+}$TG neurons that project to the Merkel cells and Sp5I.

\section{Discussion}

In the present study, to clarify the roles of Runx3 in the development of TG neurons, we analyzed TG neuron profiles and their axonal projections in Runx $3^{-/-}$mice. Runx3 suppressed TrkB expression and maintained TrkC expression in a subpopulation of $\operatorname{TrkB}^{+} / \operatorname{TrkC}^{+}$neurons, and Runx3 controlled the axonal projection of $\operatorname{TrkC}^{+}$neurons innervating the Merkel cells in the ORS of whisker vibrissae peripherally and the Sp5I centrally. These findings suggest that Runx 3 is necessary for the development of $\operatorname{TrkC}^{+}$ TG neurons that may convey mechanoreceptive signals from the Merkel cells in the ORS of whisker vibrissae to Sp5I.

\section{Runx3 is required for the axonal projection of mechanoreceptive neurons}

Several lines of evidence suggest that Runx 3 is necessary for the specification of $\mathrm{TrkC}^{+}$ proprioceptive neurons in the DRG (Inoue et al., 2002; Levanon et al., 2002; Chen et al., 2006; Kramer et al., 2006; Inoue et al., 2007; Nakamura et al., 2008). Runx3 is also expressed in a subpopulation of TG neurons from the early stages of development, but the roles of Runx3 in TG development are unknown. The TG contains cutaneous neurons, but not proprioceptive neurons, which are located in the mesencephalic trigeminal nucleus (for review, see Lazarov, 2007). In contrast to the TG, Runx3 was not expressed in the mesencephalic trigeminal nucleus (unpublished observations).

The present study showed that $\operatorname{TrkB}^{+} / \operatorname{TrkC}^{+}$axonal projection was lost in the peripheral and central targets and $\operatorname{TrkB}^{+} / \operatorname{TrkC}^{-}$axonal projection was changed in the 
central target in Run $3^{-/-}$mice at E13.5, suggesting that Runx3 may be required for there axonal projections at the early stage of development. Furthermore, $\operatorname{TrkC}^{+}$axonal projections were lost in the Merkel cells in the ORS of whisker vibrissae in the periphery and the Sp5I in the brainstem at P0, suggesting that Runx3 may be involved in the formation of mechanoreceptive afferent projections. On the other hands, TrkB ${ }^{+}$ and $\mathrm{TrkC}^{+}$afferents projecting to the reticular ending of the large whisker vibrissae were observed in both $R u n \times 3^{+/+}$and Run $x 3^{-/-}$mice. Runx3 was expressed strongly in the maxillary lobe neurons and much more weakly in the ophthalmic and mandibular lobe neurons of the TG (Fig. S5), suggesting that Runx3 may regulate the TG neurons mainly in the maxillary lobe. Three lines of evidence support the conclusion that the loss of $\mathrm{TrkC}^{+}$axonal projections in $\operatorname{Runx}^{3^{-/}}$mice is not due to the apoptosis of TG neurons. First, the number of $\mathrm{NeuN}^{+}$total $\mathrm{TG}$ neurons was not changed between Run $x 3^{+/+}$and $R u n x 3^{-/-}$mice at P0. Second, no changes in the number of apoptotic cells were observed in TG between Runx $3^{+/+}$and Run $x 3^{-/}$mice from E11.5 to P0. Finally, $\mathrm{TrkC}^{+}$axonal projections were still lost in $\mathrm{Runx}^{-/-} / \mathrm{Bax}^{-/-}$mice in which apoptosis was blocked. These results strongly suggest that Runx3 is required for the proper development of $\operatorname{TrkC}^{+} \mathrm{TG}$ neurons that project axons from the Merkel cells in the vibrissae to SP5I. Although the loss of $\mathrm{TrkC}^{+}$axonal projection may not be due to the apoptosis, we can not exclude the possibility that the defects of $\operatorname{TrkC}^{+}$axonal projections in the Merkel endings reflect the simple loss of the TrkC immunoreactivity. We are unable to address this possibility by general axonal markers, because TrkA ${ }^{+}$ axons project to this same region.

The mechanisms underlying the regulation of these axonal projections by Runx 3 remain to be examined. Previous studies reported that some TG neurons innervating the Merkel cells in the ORS of the vibrissae express TrkC, and that the Merkel nerve endings are lost when NT3/TrkC signaling is disrupted (Airaksinen et al., 1996; Fundin et al., 1997; Cronk et al., 2002; Fünfschilling et al., 2004). These studies suggest that NT3/TrkC signaling is necessary for the survival of TG neurons innervating the Merkel cells in the ORS (Airaksinen et al., 1996; Fundin et al., 1997; Cronk et al., 2002; Fünfschilling et al., 2004). It is also possible that NT3/TrkC signaling is required for axonal projections to the Merkel cells, as well as cell survival. An analysis of TrkC/Bax double knockout mice may address this possibility. Taken together, Runx3 may be involved in the axonal projections to the Merkel cells by regulating the expression of TrkC or other receptors for axonal guidance cues to the targets.

Chen et al (2006) showed that Runx3 may have a crucial role in the axonal projection of proprioceptive DRG neurons to the spinal cord. They used 
loss-of-function and gain-of-function experiments in chick embryos to show that high levels of Runx3 activity direct DRG axons to the ventral horn of the spinal cord, whereas intermediate levels of Runx3 activity direct DRG axons to the intermediate zone, and no Runx3 activity directs them to the dorsal horn. The present study suggested that Runx3 may be involved in the axonal projection of TG afferents to the spinal trigeminal nuclei. It is possible that similar mechanisms underlie the Runx3-mediated regulation of axonal projection of TG neurons and DRG neurons to their central targets.

In Drosophila, subsets of photoreceptor neurons express Runt (Run) and project their axons to the medulla, which is located in the distal part of the optic lobe. Interestingly, ectopic expression of run in photoreceptors that project to the lamina, the proximal part of the optic lobe, induces changes of the axonal projection to the medulla (Kaminker et al., 2002). Taken together, Runx family transcription factors may regulate the axonal projection of sensory neurons to central targets in both vertebrates and invertebrates.

We reported recently that $\operatorname{TrkC}^{+}$neurons in the DRG are divided into two subpopulations: Runx3-dependent early-appearing proprioceptive neurons that project to the muscle spindles peripherally and the ventral/intermediate spinal cord centrally, and Runx3-independent late-appearing cutaneous neurons that project to the skin and the dorsal spinal cord (Nakamura et al., 2008). The present study showed that Runx 3 is involved in the $\mathrm{TG}$ in the development of $\mathrm{TrkC}^{+}$mechanoreceptive neurons, and that $\mathrm{TrkC}^{+}$cutaneous neurons that innervate the facial skin are Runx3-independent.

\section{Runx3 represses TrkB expression and maintains TrkC expression in both $\mathrm{TG}$ and DRG}

The present immunohistochemical analyses showed that the numbers of $\operatorname{TrkB}^{+}$and $\mathrm{TrkC}^{+} \mathrm{TG}$ neurons were not changed in $\operatorname{Runx}^{3^{-/}}$mice at E10.5, suggesting that Runx3 is not required for the initial appearance of TrkB and TrkC. The present study also revealed that most $\operatorname{TrkB}^{+}$neurons express both TrkC and Runx3 in the TG at E10.5. By E13.5, $\operatorname{TrkB}^{+} / \operatorname{TrkC}^{+}$TG neurons were segregated to $\operatorname{TrkB}^{+} / \operatorname{TrkC}^{-}$and $\operatorname{TrkB}^{-} / \operatorname{TrkC}^{+}$ neurons, and Runx3 was expressed in the $\operatorname{TrkB}^{-} / \operatorname{TrkC}^{+}$but not the $\operatorname{TrkB}^{+} / \operatorname{TrkC}^{-}$neurons These results suggest that Runx3 may be involved in the segregation of $\operatorname{TrkB}^{+} / \operatorname{TrkC}^{+}$ TG neurons into $\operatorname{TrkB}^{+}$or $\operatorname{TrkC}^{+}$TG neurons by repressing TrkB expression and maintaining TrkC expression in a cell autonomous manner. These roles of Runx3 were supported by the analyses of $\operatorname{Run} \times 3^{-/-}$mice where $\operatorname{TrkB}^{+}$neurons were increased,

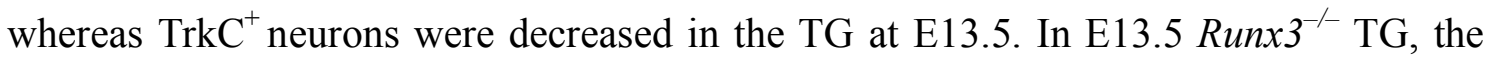


number of increased $\operatorname{TrkB}^{+} / \operatorname{TrkC}^{+}$neurons is much smaller than the number of decreased $\operatorname{TrkB}^{-} / \operatorname{TrkC}^{+}$neurons, suggesting the possibility that some prospective $\operatorname{TrkB}^{-} / \operatorname{TrkC}^{+}$neurons were converted to become $\operatorname{TrkB}^{+} / \operatorname{TrkC}^{+}$neurons, whereas the remaining half lost TrkC expression without an activation of $\operatorname{TrkB}$ at this early development stage. Similar regulation of the expression of TrkB and TrkC by Runx3 was reported in the DRG (Inoue et al., 2002; Levanon et al., 2002, Chen et al., 2006; Kramer et al., 2006; Inoue et al., 2007; Nakamura et al., 2008). During the development of the DRG, $\operatorname{TrkB}^{+} / \operatorname{TrkC}^{+}$neurons are segregated into $\operatorname{TrkB}^{+}$mechanoreceptive neurons and $\mathrm{TrkC}^{+}$proprioceptive neurons (Kramer et al., 2006; Inoue et al., 2007), and Runx3 is involved in the repression of $\operatorname{TrkB}$ expression and the maintenance of TrkC expression. Taken together, it was shown that Runx3 plays similar roles in regulating the expression of TrkB and TrkC in both TG and DRG.

\section{Regulation of the expression of neuropeptides and calcium binding proteins by Runx3 in TG and DRG}

We examined the expression of neuropeptides and calcium-binding proteins in the TG of Run $x 3^{+/+}$and Run $x 3^{-/-}$mice. The present study showed that most $\mathrm{SOM}^{+}$neurons in the TG co-expressed Runx3 in Runx $3^{+/+}$mice, and that $\mathrm{SOM}^{+}$neurons were decreased in $R u n x 3^{-/}$mice. These results suggest that Runx 3 positively regulates the expression of SOM cell-autonomously. Because the number of $\mathrm{SOM}^{+} \mathrm{TG}$ neurons is small and $\mathrm{SOM}^{+}$ axon projection to the Merkel cells in the ORS of whisker vibrissae and the Sp5I was not observed (data not shown in the present study; Rice et al., 1997), the identity of $\mathrm{SOM}^{+} \mathrm{TG}$ neurons was not clear. We recently reported that $\mathrm{SOM}^{+}$neurons were also decreased in Runx $3^{-/}$DRG (Nakamura et al., 2008). These results suggest that Runx3 may regulate SOM expression in the TG as well as DRG. We also reported that the number of $\mathrm{CGRP}^{+}$neurons is decreased in DRG of Run $\times 3^{-/-}$mice (Nakamura et al., 2008). In contrast, in the TG, CGRP expression was unchanged between $R u n \times 3^{+/+}$and Run $x 3^{-/}$mice. CGRP ${ }^{+}$neurons are nociceptive in both TG and DRG (Price and Flores, 2007). These results suggest that regulation of CGRP expression by Runx3 in TG may be different from that in the DRG.

The present study showed that the expression of PV, Calr, and CB were unchanged in TG between $R u n x 3^{+/+}$and $R u n x 3^{-/-}$mice. We recently reportSed that PV expression was virtually absent from the onset and $\mathrm{Calr}^{+}$neurons were decreased, while $\mathrm{CB}^{+}$ neurons increased in the DRG of Runx $3^{-/-}$mice (Nakamura et al., 2008). $\mathrm{PV}^{+}$neurons and a subpopulation of $\mathrm{Calr}^{+}$neurons are thought to be proprioceptive neurons in DRG (Copray et al., 1994; Honda, 1995; Kucera et al., 2002; Mu et al., 1993; Nakamura et al., 
2008). On the other hand, several previous reports suggest that $\mathrm{PV}^{+}, \mathrm{Calr}^{+}$, and $\mathrm{CB}^{+}$ neurons in the TG are nociceptive or mechanoreceptive neurons with nerve fibers that form Ruffini endings innervating the periodontal ligament (Ichikawa et al., 1993; 1994; 1995; 1996; 1997; 2004; 2005; Ichikawa and Sugimoto, 1997). We observed TrkC afferents in the periodontal ligament in both $R u n \times 3^{+/+}$and $R u n x 3^{-/-}$mice (data not shown), suggesting that Runx3 may not influence the $\operatorname{TrkC}^{+}$neurons innervating the periodontal ligament. Taken together, our data suggest that Runx3 may not participate in the development of nociceptive or mechanoreceptive neurons expressing PV, Calr, and $\mathrm{CB}$, and that Runx3 plays separate roles in the development of the TG and DRG.

\section{Experimental Methods}

\section{Genotyping and animal maintenance}

The strategy used to inactivate Runx3 in the mouse germline was described previously (Inoue et al., 2002; Li et al., 2002). Bax-deficient mice (Knudson et al., 1995) were purchased from the Jackson Laboratory (Bar Harbor, ME). Mice were bred in a clean room in the Laboratory Animal Resource Center at the University of Tsukuba. Run $x 3^{-/-}$ mice and $R u n x 3^{+/+}$mice were obtained by mating $R u n x 3^{+/-}$mice. $R u n x 3^{-/-} / B a x^{-/}$double knockout mice and $R u n \times 3^{+/+} / \mathrm{Bax}^{-/-}$control mice were obtained by mating Run $3^{+/-} / \mathrm{Bax}^{+/-}$double heterozygotes. Timed embryos were obtained by overnight mating, and the morning when the vaginal plug was observed was considered E0.5. To genotype Runx3-deficiency, PCR was performed using primer pairs wild-type (NA, 5'-GACTGTGCATGCACCTTTCACCAA-3' and CB, 5'-TAGGGCTCAGTAGCACTTACGTCG-3') or mutant (NA and C2, 5'-ATGAAACGCCGAGTTAACGCCATCA-3') allele detection. For genotying of Bax-deficiency, PCR was performed using a set of three primers: Bax exon 5 forward primer (5'-TGATCAGAACCATCATG-3'), Bax intron 5 reverse primer (5'-GTtGACCAGAGTGGCGTAGG-3'), and Neo reverse primer (5'-CCGCTTCCATTGCTCAGCGG-3'). All experiments followed the Guide for the Care and Use of Laboratory Animals described by the National Institutes of Health (USA), and were approved by the Animal Experimentation Committee of the University of Tsukuba.

\section{Immunohistochemistry}


Immunohistochemistry was performed as previously described (Nakamura et al., 2008). For cryostat sections, E10.5 to E13.5 whole mouse embryos were immersed overnight at $4{ }^{\circ} \mathrm{C}$ in a fixative containing $4 \%$ paraformaldehyde in $0.1 \mathrm{M}$ phosphate buffer $(\mathrm{pH}$ 7.4). Newborn mice were perfused transcardially with the same fixative and immersed overnight at $4^{\circ} \mathrm{C}$. The heads were dissected and immersed in $20 \%$ sucrose solution in $0.1 \mathrm{M}$ phosphate buffer and frozen in Tissue Tek O.C.T. compound (Sakura Finetek, Japan). Horizontal, sagittal, or coronal sections (10 or $12 \mu \mathrm{m})$ of heads were cut using a cryostat (HM 500 OM; Microm, Germany) and collected onto MAS-coated glass slides (Matsunami Glass, Japan) and air-dried for 1 hour. If needed, sections were subjected to heat-induced epitope retrieval by heating to $105^{\circ} \mathrm{C}$ for 5 or 10 minutes in Dako REAL ${ }^{\mathrm{TM}}$ Target Retrieval Solution (Dako). After treatment for 30 minutes at room temperature (RT) with $0.3 \% \mathrm{H}_{2} \mathrm{O}_{2}$ in methanol, the sections were incubated for 1 hour at RT in a blocking solution containing $1 \%$ bovine serum albumin and $0.1 \%$ to $0.5 \%$ Triton $\mathrm{X}-100$ in phosphate-buffered saline.

For immunohistochemical analysis, the following antibodies were used: mouse anti-Runx3 (Abnova; 1:2000), rabbit anti-TrkA (RTA; a gift from Dr. L. F. Reichardt, University of California, San Francisco, CA; 1:4000), rabbit anti-TrkB (Upstate; 1:1000), goat anti-TrkC (R\&D Systems; 1:1500), rabbit anti-somatostatin (SOM; Protos Biotech; 1:2000), rabbit anti-parvalbumin (PV; Swant; 1:2000), mouse anti-NeuN (Chemicon; 1:5000), rabbit anti-calretinin (Calr; Swant; 1:2000), rabbit anti-calbindin D-28K (CB; Swant; 1:1000), rabbit anti-calcitonin gene-related peptide (CGRP, Chemicon; 1:4000), and anti-substance-P (SubP, Protos Biotech; 1:2000) antibodies. The sections were incubated for 24 to 48 hours at $4^{\circ} \mathrm{C}$ with each of the primary antibodies. For single staining, the sections were incubated with a biotinylated secondary antibody (Vector Laboratories; 1:500) for 1 hour at RT, followed with the peroxidase-conjugated avidin-biotin complex (Vector Laboratories; 1:100) for 30 minutes at RT. For double or triple staining, cryostat sections were incubated with anti-Runx3 antibody, followed by incubation with biotinylated horse anti-mouse IgG antibody (Vector Laboratories; 1:500) and Pacific Blue-conjugated streptavidin (Invitrogen; 1:500). The sections were then incubated with antibody against TrkA, TrkB, TrkC, SOM, or PV, followed by Alexa Fluor 488-labeled donkey anti-rabbit or anti-goat IgG antibody or Alexa Fluor 594-labeled donkey anti-rabbit or anti-goat IgG antibody (Invitrogen; 1:1000). Images of immunostained samples were collected on a LSM510META confocal laser microscope (Carl Zeiss). Samples from Runx $3^{-/}$and Run $x 3^{+/+}$littermates and $R u n x 3^{-/-} / \mathrm{Bax}^{-/-}$and $\mathrm{Runx}^{+/ /} / \mathrm{Bax}^{-/-}$littermates were processed simultaneously for immunohistochemistry, respectively. 


\section{Cell counting and statistical analysis}

For cell counts, large images of TG sections were captured with a CCD camera on an A600 microscope with a MosaiX tiling image module (Carl Zeiss) or an LSM510META confocal laser microscope (Carl Zeiss) using a 20x objective. To estimate the number of immunoreactive (IR) neurons per TG, the number of IR neurons was counted in all sections of a 1 in 10 series for newborn mice, or of a 1 in 5 series for E10.5 to E13.5 mice, multiplying the average number of IR neurons per section by the number of total sections. As described previously (Nakamura et al., 2008), neurons were counted if they contained a nucleus and had a signal intensity in the cytoplasm or nucleus that was more than 2.5-fold above the noise level for that tissue section. The total number of IR neurons was counted from the TGs from each genotype (3-6 TGs from three animals at each stage were examined). Quantitative analyses were performed on three pairs of embryos or newborns from three independent pregnant mice. Statistical analyses were performed using the $F$ test, followed by the Student's $t$ test. Differences were considered significant if the probability of error was less than $5 \%$. All results are expressed as the mean $\pm \mathrm{SEM}$.

\section{Acknowledgements}

We thank Dr. L.F. Reichardt for providing the antibodies against TrkA. This study was supported by a Grant-in-Aid for Scientific Research from the 21st Century COE Program from the Ministry of Education, Culture, Sports, Science, and Technology (MEXT) of Japan to S.O., M.Y., and T.S., a Grant-in-Aid for Young Scientists (B) to K.S. from MEXT, and a Grant-in-Aid for Scientific Research (B) to T.S. from MEXT. 


\section{References}

Airaksinen, M.S, Koltzenburg, M., Lewin, G.R., Masu, Y., Helbig, C., Wolf, E., Brem, G., Toyka, K.V., Thoenen, H., Meyer, M., 1996. Specific subtypes of cutaneous mechanoreceptors require neurotrophin-3 following peripheral target innervation. Neuron 16, 287-295.

Baker, C.V., Bronner-Fraser, M., 2001. Vertebrate cranial placodes I. Embryonic induction. Dev. Biol. 232, 1-61.

Chan, W.Y., Tam, P.P.L., 1988. A morphological and experimental study of the mesencephalic neural crest cells in the mouse embryo using wheat germ agglutinin-gold conjugate as the cell marker. Development 102, 427-442.

Chen, A.I., de Nooij, J.C., Jessell, T.M., 2006. Graded activity of transcription factor Runx3 specifies the laminar termination pattern of sensory axons in the developing spinal cord. Neuron 49, 395-408.

Coffman, J.A., 2003. Runx transcription factors and the developmental balance between cell proliferation and differentiation. Cell Biol. Int. 27, 315-324.

Copray, J.C., Mantingh-Otter, I.J., Brouwer, N., 1994. Expression of calcium-binding proteins in the neurotrophin-3-dependent subpopulation of rat embryonic dorsal root ganglion cells in culture. Brain Res. Dev. Brain Res. 81, 57-65.

Cronk, K.M., Wilkinson, G.A., Grimes, R., Wheeler, E.F., Jhaveri, S., Fundin, B.T., Silos-Santiago, I., Tessarollo, L., Reichardt, L.F., Rice, F.L., 2002. Diverse dependencies of developing Merkel innervation on the trkA and both full-length and truncated isoforms of trkC. Development 129, 3739-3750.

Fundin, B.T., Silos-Santiago, I., Ernfors, P., Fagan, A.M., Aldskogius, H., DeChiara, T.M., Phillips, H.S., Barbacid, M., Yancopoulos, G.D., Rice, F.L., 1997. Differential 
dependency of cutaneous mechanoreceptors on neurotrophins, trk receptors, and P75 LNGFR. Dev. Biol. 190, 94-116.

Fünfschilling, U., Ng, Y.G., Zang, K., Miyazaki, K., Reichardt. L.F., Rice, F.L., 2004. TrkC kinase expression in distinct subsets of cutaneous trigeminal innervation and nonneuronal cells. J. Comp. Neurol. 480, 392-414.

Honda, C.N., 1995. Differential distribution of calbindin-D28k and parvalbumin in somatic and visceral sensory neurons. Neuroscience 68, 883-892.

Ichikawa, H., Deguchi, T., Fujiyoshi, Y., Nakago, T., Jacobowitz, D.M., Sugimoto, T., 1996. Calbindin-D28k-immunoreactivity in the trigeminal ganglion neurons and molar tooth pulp of the rat. Brain Res. 715, 71-78.

Ichikawa, H., Deguchi, T., Mitani, S., Nakago, T., Jacobowitz, D.M., Yamaai T., Sugimoto, T., 1994. Neural parvalbumin and calretinin in the tooth pulp. Brain Res. 647, $124-130$.

Ichikawa, H., Deguchi, T., Nakago, T., Jacobowitz, D.M., Sugimoto, T., 1995. Parvalbumin- and calretinin-immunoreactive trigeminal neurons innervating the rat molar tooth pulp. Brain Res. 679, 205-211.

Ichikawa, H., Jacobowitz, D.M., Sugimoto, T., 1993. Calretinin-immunoreactive neurons in the trigeminal and dorsal root ganglia of the rat. Brain Res. 617, 96-102.

Ichikawa, H., Jacobowitz, D.M., Sugimoto, T., 1997. Coexpression of calretinin and parvalbumin in Ruffini-like endings in the rat incisor periodontal ligament. Brain Res. 770, 294-297.

Ichikawa, H., Jin, H.W., Terayama, R., Yamaai, T., Jacobowitz, D.M., Sugimoto, T., 2005. Calretinin-containing neurons which co-express parvalbumin and calbindin D-28k in the rat spinal and cranial sensory ganglia; triple immunofluorescence study. 
Brain Res. 1061, 118-23.

Ichikawa, H., Matsuo, S., Silos-Santiago, I., Jacquin, M.F., Sugimoto, T., 2004. The development of myelinated nociceptors is dependent upon trks in the trigeminal ganglion. Acta. Histochem. 106, 337-343.

Ichikawa, H., Sugimoto, T., 1997. Parvalbumin- and calbindin D-28k-immunoreactive innervation of orofacial tissues in the rat. Exp. Neurol. 146, 414-418.

Inoue, K., Ozaki, S., Shiga, T., Ito, K., Masuda, T., Okado, N., Iseda, T., Kawaguchi, S., Ogawa, M., Bae, S.C., Yamashita, N., Itohara, S., Kudo, N., Ito, Y., 2002. Runx3 controls the axonal projection of proprioceptive dorsal root ganglion neurons. Nat. Neurosci. 5, 946-954.

Inoue, K., Ito, K., Osato, M., Lee, B., Bae, S.C., Ito, Y., 2007. The transcription factor Runx3 represses the neurotrophin receptor TrkB during lineage commitment of dorsal root ganglion neurons. J. Biol. Chem. 282, 24175-24184.

Inoue, K., Shiga, T., Ito, Y., 2008. Runx transcription factors in neuronal development. Neural Develop. 3:20.

Ito, Y., 2004. Oncogenic potential of the RUNX gene family: overview. Oncogene 23, 4198-4208.

Ito, Y., 2008. RUNX genes in development and cancer: regulation of viral gene expression and the discovery of RUNX family genes. Adv. Cancer Res. 99, 33-76.

Kaminker, J.S., Canon, J., Salecker, I., Banerjee, U., 2002. Control of photoreceptor axon target choice by transcriptional repression of Runt. Nat. Neurosci. 5, 746-750. 
Knudson, C.M., Tung, K.S., Tourtellotte, W.G., Brown, G.A. Korsmeyer, S.J., 1995. Bax-deficient mice with lymphoid hyperplasia and male germ cell death. Science 270, 96-99.

Kramer, I., Sigrist, M., de Nooij, J. C., Taniuchi, I., Jessell, T.M., Arber, S., 2006. A role for Runx transcription factor signaling in dorsal root ganglion sensory neuron diversification. Neuron 49, 379-393.

Kucera, J., Cooney, W., Que, A., Szeder, V., Stancz-Szeder, H., Walro, J., 2002. Formation of supernumerary muscle spindles at the expense of Golgi tendon organs in ER81-deficient mice. Dev. Dyn. 223, 389-401.

Lazarov, N.E., 2002. Comparative analysis of the chemical neuroanatomy of the mammalian trigeminal ganglion and mesencephalic trigeminal nucleus. Prog. Neurobiol. $66,19-59$.

Lazarov, N.E., 2007. Neurobiology of orofacial proprioception. Brain Res. Rev. 56, 362-383.

Levanon, D., Bettoun, D., Harris-Cerruti, C., Woolf, E., Negreanu, V., Eilam, R., Bernstein, Y., Goldenberg, D., Xiao, C., Fliegauf, M., Kremer, E., Otto, F., Brenner, O., Lev-Tov, A., Groner, Y., 2002. The Runx3 transcription factor regulates development and survival of TrkC dorsal root ganglia neurons. EMBO J. 21, 3454-3463.

Li, Q.L., Ito, K., Sakakura, C., Fukamachi, H., Inoue, K., Chi, X.Z., Lee, K.Y., Nomura, S., Lee, C.W., Han, S.B., Kim, H.M., Kim, W.J., Yamamoto, H., Yamashita, N., Yano, T., Ikeda, T., Itohara, S., Inazawa, J., Abe, T., Hagiwara, A., Yamagishi, H., Ooe, A., Kaneda, A., Sugimura, T., Ushijima, T., Bae, S.C., Ito, Y., 2002. Causal relationship between the loss of RUNX3 expression and gastric cancer. Cell 109, 113-124.

Marmigère, F., Ernfors, P., 2007. Specification and connectivity of neuronal subtypes in the sensory lineage. Nat. Rev. Neurosci. 8, 114-127. 
Mu X., Silos-Santiago, I., Carroll, S.L., Snider, W.D., 1993. Neurotrophin receptor genes are expressed in distinct patterns in developing dorsal root ganglia. J. Neurosci. $13,4029-4041$.

Nakamura, S., Senzaki, K., Yoshikawa, M., Nishimura, M., Inoue, K., Ito, Y., Ozaki, S., Shiga, T., 2008. Dynamic regulation of the expression of neurotrophin receptors by Runx3. Development 135, 1703-1711

Paxinos, G., Halliday, G., Watson, C., Koutcherov, Y., Wang, H., 2007. Atlas of the developing mouse brain at E17.5, P0, and P6. Academic Press, San Diego.

Price, T.J., Flores, C.M., 2007. Critical evaluation of the colocalization between calcitonin gene-related peptide, substance $\mathrm{P}$, transient receptor potential vanilloid subfamily type 1 immunoreactivities, and isolectin B4 binding in primary afferent neurons of the rat and mouse. J. Pain 8, 263-272.

Rice, F.L., Fundin, B.T., Arvidsson, J., Aldskogius, H., Johansson, O., 1997. Comprehensive immunofluorescence and lectin binding analysis of vibrissal follicle sinus complex innervation in the mystacial pad of the rat. J. Comp. Neurol. 385, 149-184.

Simeone, A., Daga, A., Calabi, F., 1995. Expression of runt in the mice embryo. Dev. Dyn. 203, 61-70.

Theriault, F.M., Nuthall, H.N., Dong, Z., Lo, R., Barnabe-Heider, F., Miller, F.D., Stifani, S., 2005. Role for Runx1 in the proliferation and neuronal differentiation of selected progenitor cells in the mammalian nervous system. J. Neurosci. 25, 2050-2061.

Theriault, F.M., Roy, P., Stifani, S., 2004. AML1/Runx1 is important for the development of hindbrain cholinergic branchiovisceral motor neurons and selected cranial sensory neurons. Proc. Natl. Acad. Sci. U.S.A. 101, 10343-10348. 
White, F.A., Keller-Peck, C.R., Knudson, C.M., Korsmeyer, S.J., Snider, W.D., 1998. Widespread elimination of naturally occurring neuronal death in Bax-deficient mice. J. Neurosci. 18, 1428-1439.

Yoshikawa, M., Senzaki, K., Yokomizo, T., Takahashi, S., Ozaki, S., Shiga, T., 2007. Runx1 selectively regulates cell fate specification and axonal projections of dorsal root ganglion neurons. Dev. Biol. 303, 663-674. 
Figures

\section{Figure legends}

Figure 1 Changes in the number of TG neuron subtypes in $R u n x 3^{-/-}$mice at $\mathrm{P0}$. (A'-F',A''-F'') Immunoreactivity of NeuN as a pan-neuronal marker (A',A'), TrkA (B',B'), TrkB (C',C',), TrkC (D',D'), parvalbumin (PV; E',E'), and somatostatin

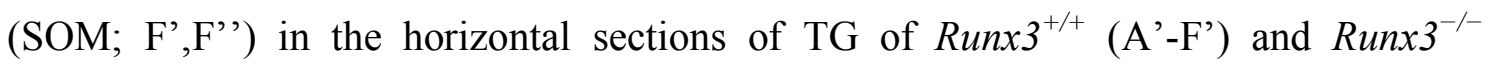
(A'-F') mice at P0. The direction of the sections are shown in F', C: caudal, M: medical. Boxed areas of immunoreactive neurons are shown at higher magnification in the insets at the right bottom of each panel (A"'-F"') Quantification of the total number of TG neurons (A"') and TG neuron subtypes (B",'-F"', in $R u n \times 3^{+/+}$(white bars) and $R_{u n} \times 3^{-/}$(black bars) mice. Data are shown as mean \pm SEM; $* P<0.0001$. Scale bar: $200 \mu \mathrm{m}$ in A.

Figure 2 Co-expression of Runx3 and TG neuron subtype markers at P0. (A'-F') Triple staining of TrkB (green), TrkC (red), and Runx3 (blue) (A',B'); somatostatin (SOM; green), TrkC (red), and Runx3 (blue) (C',D'); and parvalbumin (PV; green), TrkC (red), and Runx3 (blue) (E',F') in the sagittal sections of Runx3 ${ }^{+/+}$TG (A',C',E') and $R u n x 3^{-/-}$TG (B',D',F'). The direction of the sections are shown in B'. C: caudal, D: dorsal. Boxed areas of immunoreactive neurons are shown at higher magnification in the insets at the top right of each panel. (A'-F") The Venn diagrams show the interrelationship of the expression of Runx3, TrkC, and TG neuron subtype markers. The area of each circle corresponds to the number of immunoreactive neurons. (G-I) Quantification of the number of $\operatorname{TrkB}^{-} / \operatorname{TrkC}^{+}, \operatorname{TrkB}^{+} / \operatorname{TrkC}^{-}, \operatorname{TrkB}^{+} / \operatorname{TrkC}^{+}(\mathrm{G})$, $\mathrm{SOM}^{-} / \operatorname{TrkC} C^{+}, \mathrm{SOM}^{+} / \operatorname{TrkC}{ }^{-}, \mathrm{SOM}^{+} / \operatorname{TrkC}{ }^{+}(\mathrm{H})$, and $\mathrm{PV}^{-} / \operatorname{TrkC}^{+}, \mathrm{PV}^{+} / \operatorname{TrkC}^{-}, \mathrm{PV}^{+} / \operatorname{TrkC}^{+}$ (I) TG neurons in $\operatorname{Runx}^{+/+}(+/+)$and $\operatorname{Runx}^{-/-}(-/-)$mice. The colors used in the Venn diagrams and the bar graphs are the same as those indicating the triple staining. Data are shown as mean $\pm \mathrm{SEM} ;{ }^{*} P<0.05, * * * P<0.001$. Scale bar: $200 \mu \mathrm{m}$ in $\mathrm{A}^{\prime}$, scale circle: 300 neurons in $F^{\prime \prime}$.

Figure 3 Changes in the number of $\operatorname{TrkB}^{+}$and $\operatorname{TrkC}^{+}$TG neurons in Runx $^{-/-}$ mice during early development. (A-D) Immunoreactivity of $\operatorname{TrkB}(A, B)$ and $\operatorname{TrkC}$ (C,D) in the sagittal sections of TG of $\operatorname{Runx}^{+/+}(\mathrm{A}, \mathrm{C})$ and $R u n \times 3^{-/-}(\mathrm{B}, \mathrm{D})$ mice at E10.5 (A'-D'), E11.5 (A''-D'), E12.5 (A'"'-D','), and E13.5 (A','-D','). The direction of the sections are shown in $\mathrm{A}^{\prime \prime,}, \mathrm{D}$ : dorsal, R: rostral. Boxed areas of 
immunoreactive neurons are shown at higher magnification in the insets at the bottom left of each panel. (E,F) Quantifications of the number of $\operatorname{TrkB}^{+}(\mathrm{E})$ and $\operatorname{TrkC}^{+}(\mathrm{F}) \mathrm{TG}$

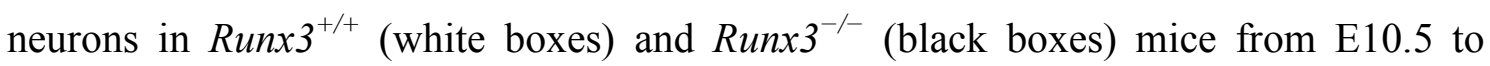
E13.5. Data are shown as mean \pm SEM; $* P<0.05$, ** $P<0.01$, *** $P<0.001$. Scale bars: $150 \mu \mathrm{m}$ in D'-D',,'.

Figure 4 Co-expressions of TrkB and TrkC in Runx3 ${ }^{-/-}$TG at E10.5 and E13.5. (A'-D') Triple staining of TrkB (green), TrkC (red), and Runx3 (blue) in the sagittal sections of $R u n x 3^{+/+}$(A',B') and $R u n x 3^{-/-}$(C',D') TG at E10.5 (A',C') and E13.5 (B',D'). The direction of the sections are shown in A'. C: caudal, D: dorsal. Boxed areas of immunoreactive neurons are shown at higher magnification in the insets at the right bottom of each panel. (A'-D') The Venn diagrams show the interrelationship of the expression of TrkB, TrkC, and Runx3 at E10.5 (A',C') and E13.5 (B',D'). The area of each circle corresponds to the number of immunoreactive neurons. (E,F) Quantifications of the number of $\operatorname{TrkB}^{-} / \operatorname{TrkC}^{+}, \operatorname{TrkB}^{+} / \operatorname{TrkC} C^{-}$, and $\operatorname{TrkB}^{+} / \operatorname{TrkC}^{+} \mathrm{TG}$ neurons in $\operatorname{Runx}^{+/+}(+/+)$and $\operatorname{Runx}^{-/-}(-/-)$mice at E10.5 (E) and E13.5 (F). The colors used in the Venn diagrams and the bar graphs are the same as those indicating the triple staining. Data are shown as mean $\pm \mathrm{SEM}$; $* * * P<0.0001$. Scale bars: $250 \mu \mathrm{m}$ in C',D'; scale circle: 300 neurons in D',.

Figure 5 TG axon projections to the peripheral targets in $\operatorname{Runx}^{+/+}$and $\operatorname{Runx}^{-/-}$ mice at E13.5. (A-F) Double staining of $\operatorname{TrkC}(A, B$, red in E,F) and $\operatorname{TrkB}(\mathrm{C}, \mathrm{D}$, green in E,F) in the maxillary region of the coronal sections of Runx $3^{+/+}(\mathrm{A}, \mathrm{C}, \mathrm{E})$ and Run $x 3^{-/-}$ $(\mathrm{B}, \mathrm{D}, \mathrm{F})$ mice from the same litters. The direction of the sections are shown in E'. $\mathrm{D}$ : dorsal, M: medial. Boxed areas of immunoreactive axons in $\mathrm{A}^{\prime}-\mathrm{F}^{\prime}$ are shown at higher magnification in each of the right two panels, respectively (A''-F', $A$ ',' $-F$ ','). TrkC afferents project to the large whisker vibrissae ( $\mathrm{L}$ in $\mathrm{A}$ ') and small whisker vibrissae (S in $\mathrm{A}^{\prime \prime \prime}$ ) in $\operatorname{Runx}^{+/+}$(A), but not in $\operatorname{Runx}^{-/-}$(L in B', $\mathrm{S}$ in B"') mice, while TrkB ${ }^{+}$ afferents project to the large whisker vibrissae ( $\mathrm{L}$ in $\mathrm{C}$ ', $\mathrm{D}$ ') ) and small whisker vibrissae (S in C', ', D',') in both $R u n x 3^{+/+}$(C) and $R u n x 3^{-/-}$(D) mice. L: large whisker vibrissa, $\mathrm{S}$ : small whisker vibrissae. Scale bar: $250 \mu \mathrm{m}$ in $\mathrm{F}^{\prime}$.

Figure 6 TG axon projections to the central targets in $R u n x 3^{+/+}$and $R u n x 3^{-/-}$mice, and $\operatorname{Runx}^{+/+} / \mathrm{Bax}^{-/-}$and $\operatorname{Runx}^{-/-} / \mathrm{Bax}^{-/-}$mice at E13.5. (A-D) Double staining of TrkB (A','-D',', green in A'-D',A',',-D',') and TrkC (A',-D', red in $\left.A^{\prime}-D^{\prime}, A^{\prime \prime, '}-D^{\prime,, '}\right)$ in the coronal sections of metencephalon (Met; A,C) and 
myelencephalon (Myel; B,D) of $\operatorname{Runx}^{+/+}(\mathrm{A}, \mathrm{B})$ and $\operatorname{Runx}^{-/-}$(C,D) mice from the same litters. The direction of the sections are shown in A'. D: dorsal, L: lateral. Boxed areas of immunoreactive axons in $A^{\prime}$ - $D^{\prime}$ are shown at higher magnification in the each right three panels, respectively (A' -D',A','-D"',A',',-D',',). TrkC $\mathrm{C}^{+}$axon projections were observed in the spinal trigeminal tract $(\mathrm{Sp} 5 \mathrm{t})$, the lateral portion of metencephalon

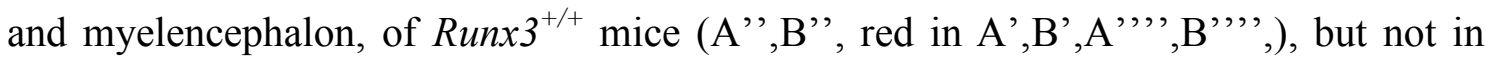
Run $\times 3^{-/-}$mice (C',C', C',', D',D',,D','). Arrows indicate aberrant $\operatorname{TrkB}^{+}$axon projections in the lateral portion of $\mathrm{Sp} 5 \mathrm{t}$ of $\operatorname{Run} 3^{-/-}$mice (D',', green in $\mathrm{D}^{\prime,}{ }^{\prime \prime}$ ). Arrowheads indicate $\operatorname{TrkC}^{+}$vestibulocochlear nerve in the myelencephalon of Runx $3^{+/+}$

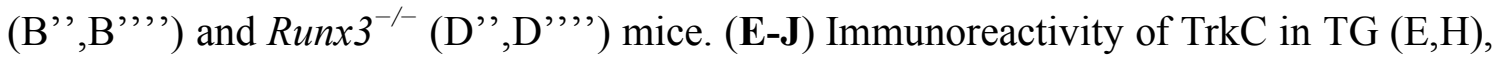
metencephalon $(\mathrm{F}, \mathrm{I})$ and myelencephalon $(\mathrm{G}, \mathrm{J})$ of $\operatorname{Runx}^{+/+} / \mathrm{Bax}^{-/-}$(E-G) and Run $3^{-/-} / \mathrm{Bax}^{-/-}$(H-J) mice at E13.5 from the same litters. Boxed areas of immunoreactive TG neurons in $\mathrm{E}$ and $\mathrm{H}$ are shown at higher magnification in the insets at the right bottom of each panel. Boxed areas of immunoreactive axons in F', G', I', J' are shown at higher magnification in each of the right panels ( $F$ ', G', I', J' '). TrkC axon projections were observed in Sp5t of Runx $3^{+/+} / \mathrm{Bax}^{-/-}$mice $(\mathrm{F}, \mathrm{G})$, but not in $\operatorname{Runx}^{-/-} / \mathrm{Bax}^{-/-}$mice $(\mathrm{I}, \mathrm{J})$. Arrowheads indicate $\mathrm{TrkC}^{+}$vestibulocochlear nerve in the

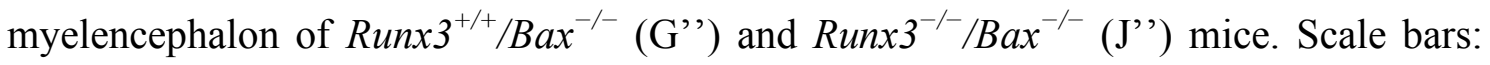
$250 \mu \mathrm{m}$ in $\mathrm{D}^{\prime}, \mathrm{J}$ '; $100 \mu \mathrm{m}$ in $\mathrm{H}$.

Figure 7 TG axon projections to the Merkel cells in the ORS of large and small vibrissae in $\boldsymbol{R u n x}^{+/ /+}$and $\boldsymbol{R} u n x \boldsymbol{3}^{-/-}$mice at P0. (A-F) Double staining of TrkC (A'-F', red in $A$," $-F$ ',') and TrkB (A',-F', green in A','-F',') in the large whisker vibrissae of $R u n x 3^{+/+}$(A-C) and Runx $3^{-/-}$(D-F) mice from the same litters. Boxed areas of immunoreactive axons $\mathrm{B}, \mathrm{C}$ in $\mathrm{A}$ ", and $\mathrm{E}, \mathrm{F}$ in $\mathrm{D}$ ", are shown at higher magnification in the right three panels, respectively $(\mathrm{B}, \mathrm{C}, \mathrm{E}, \mathrm{F}) . \mathrm{TrkC}^{+}$afferents project to the Merkel cells in the ORS of large vibrissae in $\operatorname{Runx}^{+/+}$(A', $\mathrm{A}^{\prime \prime \prime}$, arrows in $\mathrm{B}^{\prime}, \mathrm{B}^{\prime}$, '), but not in Runx $3^{-/-}$(D',D','E',E',') mice, whereas very few $\operatorname{TrkB}^{+}$afferents project to the

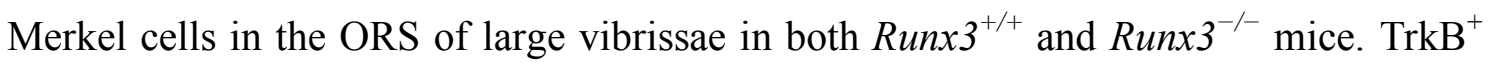
and $\mathrm{TrkC}^{+}$afferents projecting to the reticular ending were observed in both Runx $3^{+/+}$

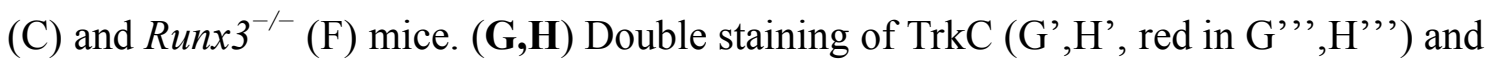
TrkA (G', $\mathrm{H}^{\prime}$, green in $\mathrm{G}^{\prime},{ }^{,} \mathrm{H}^{\prime}$, ') in the small whisker vibrissae and the skin of $\operatorname{Runx}^{+/+}(\mathrm{G})$ and $R u n x 3^{-/-}(\mathrm{H})$ mice from the same litters. TrkC $\mathrm{C}^{+}$afferents project to the Merkel cells in the ORS of small vibrissae in $R u n \times 3^{+/+}$(arrows in G',G','), but not in $R u n x 3^{-/-}\left(\mathrm{H}^{\prime}, \mathrm{H}^{\prime \prime},\right)$ mice, while TrkA ${ }^{+}$afferents project to the Merkel cells in ORS of small vibrissae in both $\operatorname{Run} \times 3^{+/+}$and $R u n \times 3^{-/-}$mice (G', $\mathrm{H}^{\prime}$, green in G', $\left., \mathrm{H}^{\prime},{ }^{\prime}\right)$. 
$\operatorname{TrkC}^{+} / \operatorname{TrkA}^{+}$afferents project to the facial skin in both $R u n x 3^{+/+}$and $R u n x 3^{-/-}$mice (arrowheads in G,H). Scale bars: $100 \mu \mathrm{m}$ in $\mathrm{A}^{\prime \prime, ', ~} \mathrm{H}^{\prime \prime}, ; 50 \mu \mathrm{m}$ in $\mathrm{C}^{\prime,}$,.

Figure 8 TG axon projections to the brainstem in $R u n x 3^{+/+}$and $R u n x 3^{-/-}$mice at P0. (A,B) Double staining of $\operatorname{TrkC}\left(\mathrm{A}^{\prime}{ }^{,}, \mathrm{B}^{\prime}\right.$, , red in $\left.\mathrm{A}^{\prime}, \mathrm{B}^{\prime}, \mathrm{A}^{\prime,},{ }^{\prime}, \mathrm{B}^{\prime,},{ }^{\prime}\right)$ and $\operatorname{TrkB}$ (A',',B',', green in $\mathrm{A}^{\prime}, \mathrm{B}^{\prime}, \mathrm{A}^{\prime,},{ }^{\prime}, \mathrm{B},{ }^{\prime \prime}$, ) in the coronal sections of brainstem (BS) of

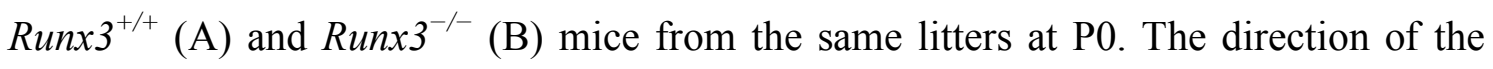
sections are shown in B'. D: dorsal, M: medial. Boxed areas of immunoreactive axons in $A^{\prime}, B^{\prime}$ are shown at higher magnification in each of the right three panels, respectively (A'-A',',B',-B','). The white dotted line outlines the spinal trigeminal nucleus pars interpolaris (Sp5I; upper dotted lines) and caudalis (Sp5C; lower dotted lines), based on an atlas of the developing mouse brain at P0 (Paxinos et al., 2007). $\mathrm{TrkC}^{+}$axons project to Sp5I and Sp5C in $R u n \times 3^{+/+}$mice (A', red in $\mathrm{A}^{\prime}, \mathrm{A}^{\prime},{ }^{\prime \prime}$ '), but not to Sp5I in Runx $3^{-/-}$mice (B', red in $\left.\mathrm{B}^{\prime}, \mathrm{B}^{\prime \prime},{ }^{\prime}\right)$, while $\operatorname{TrkB}^{+}$axons project to Sp5C and

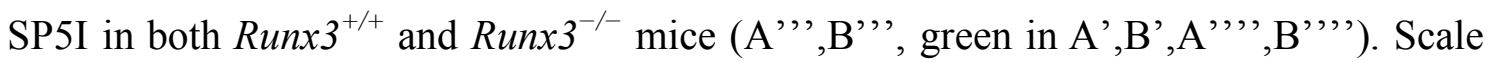
bars: $500 \mu \mathrm{m}$ in $\mathrm{A}^{\prime}, 250 \mu \mathrm{m}$ in $\mathrm{A}^{\prime \prime, ', ~}$ 
Fig.1
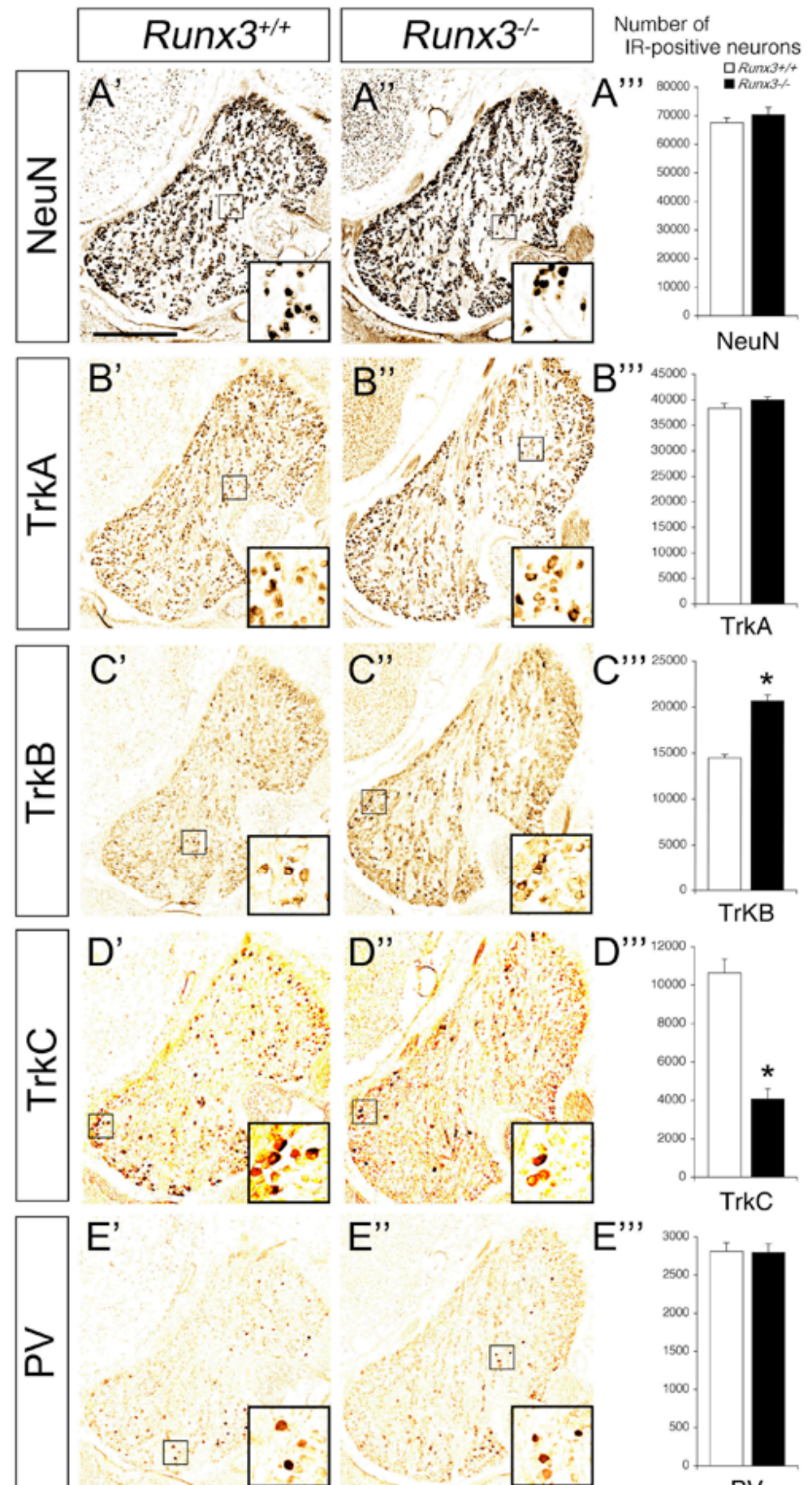

E"
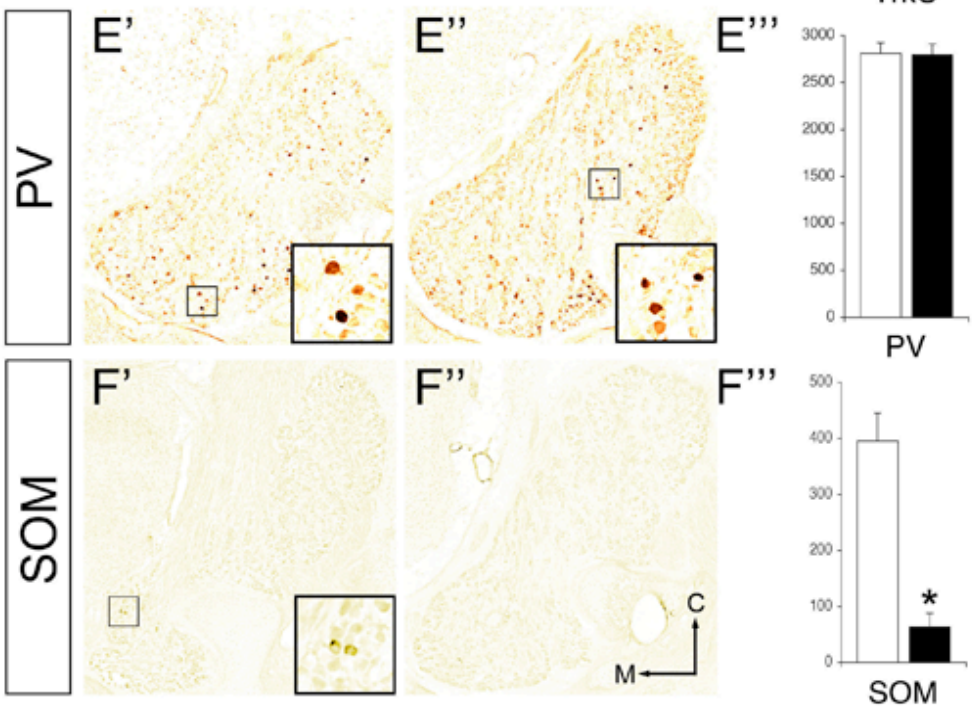

F"

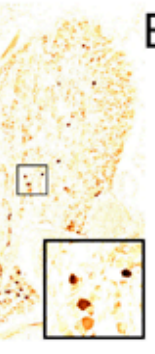

$F^{\prime \prime}$

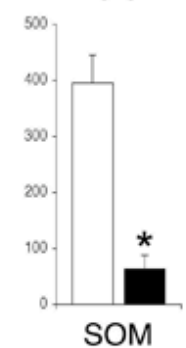


Fig. 2
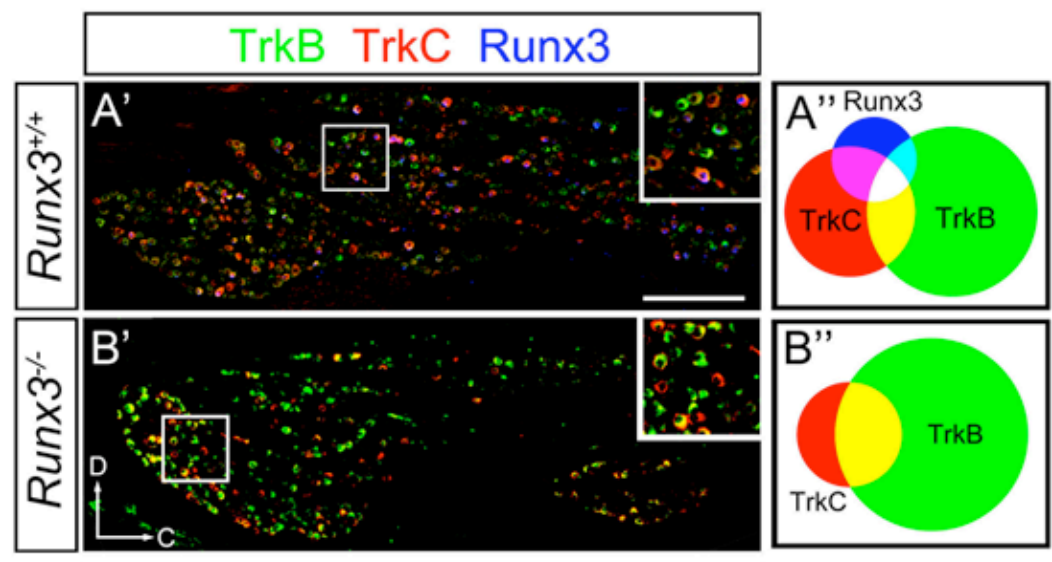

Number of IR-positive neurons
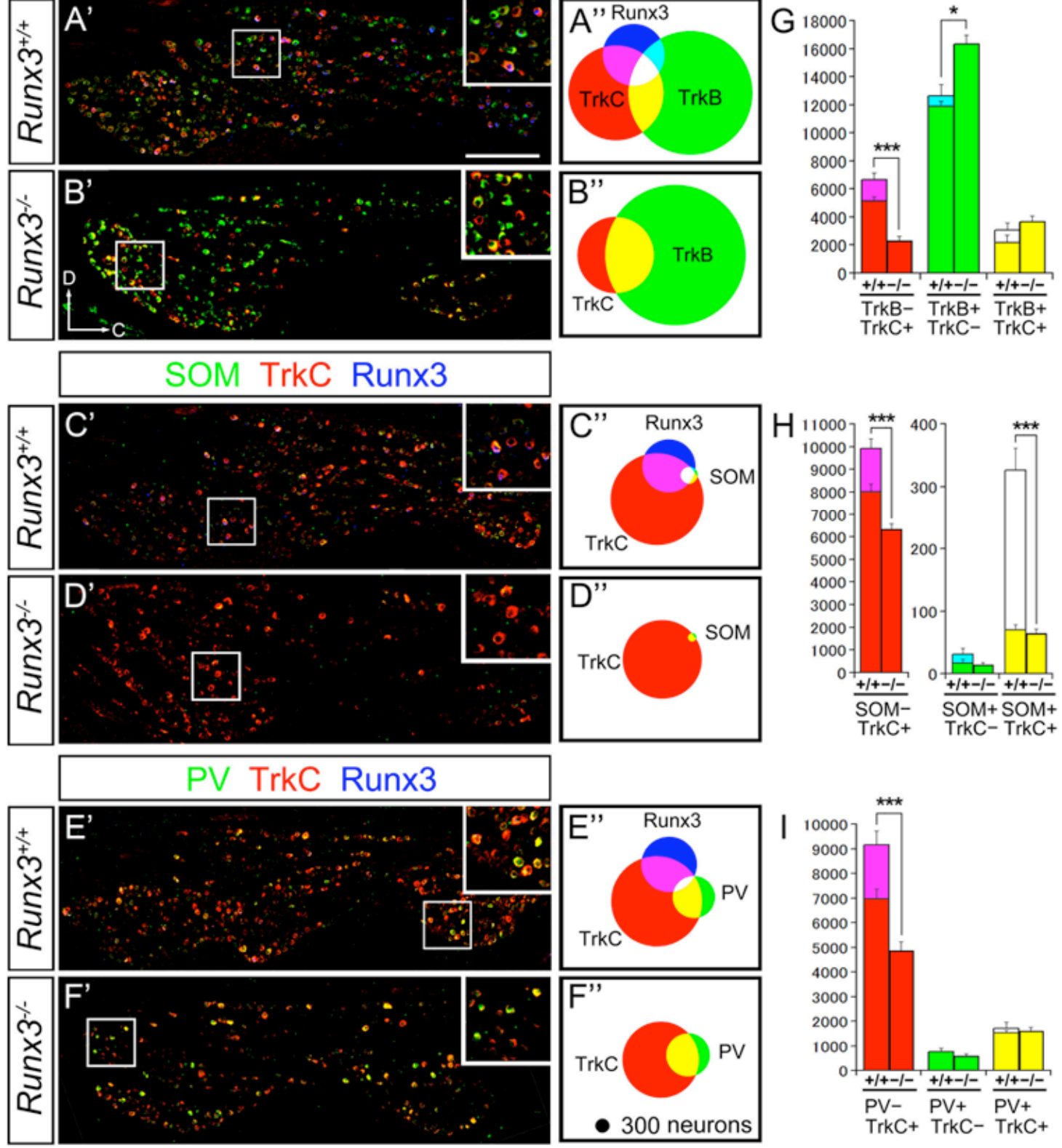
Fig. 3
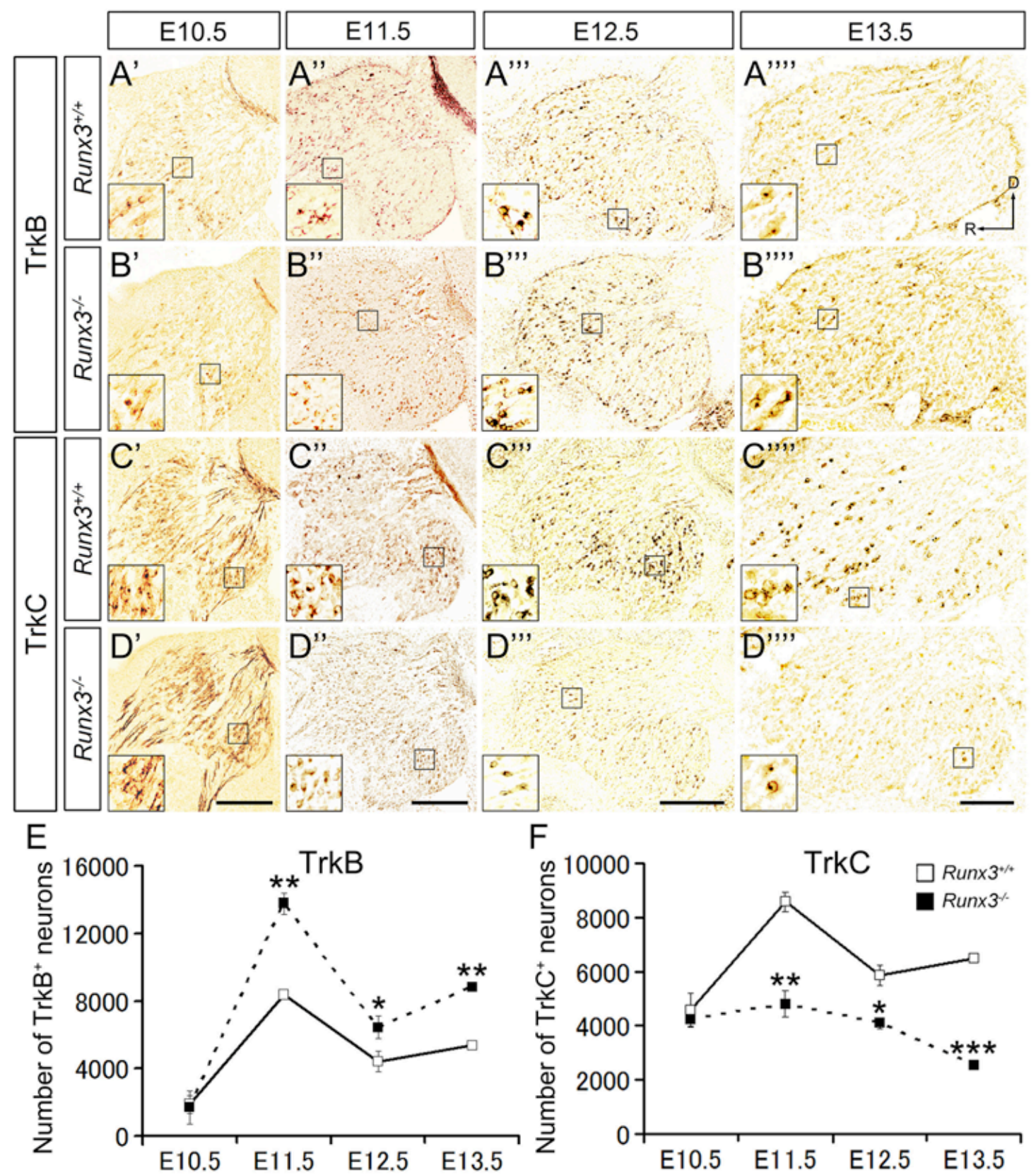
Fig. 4
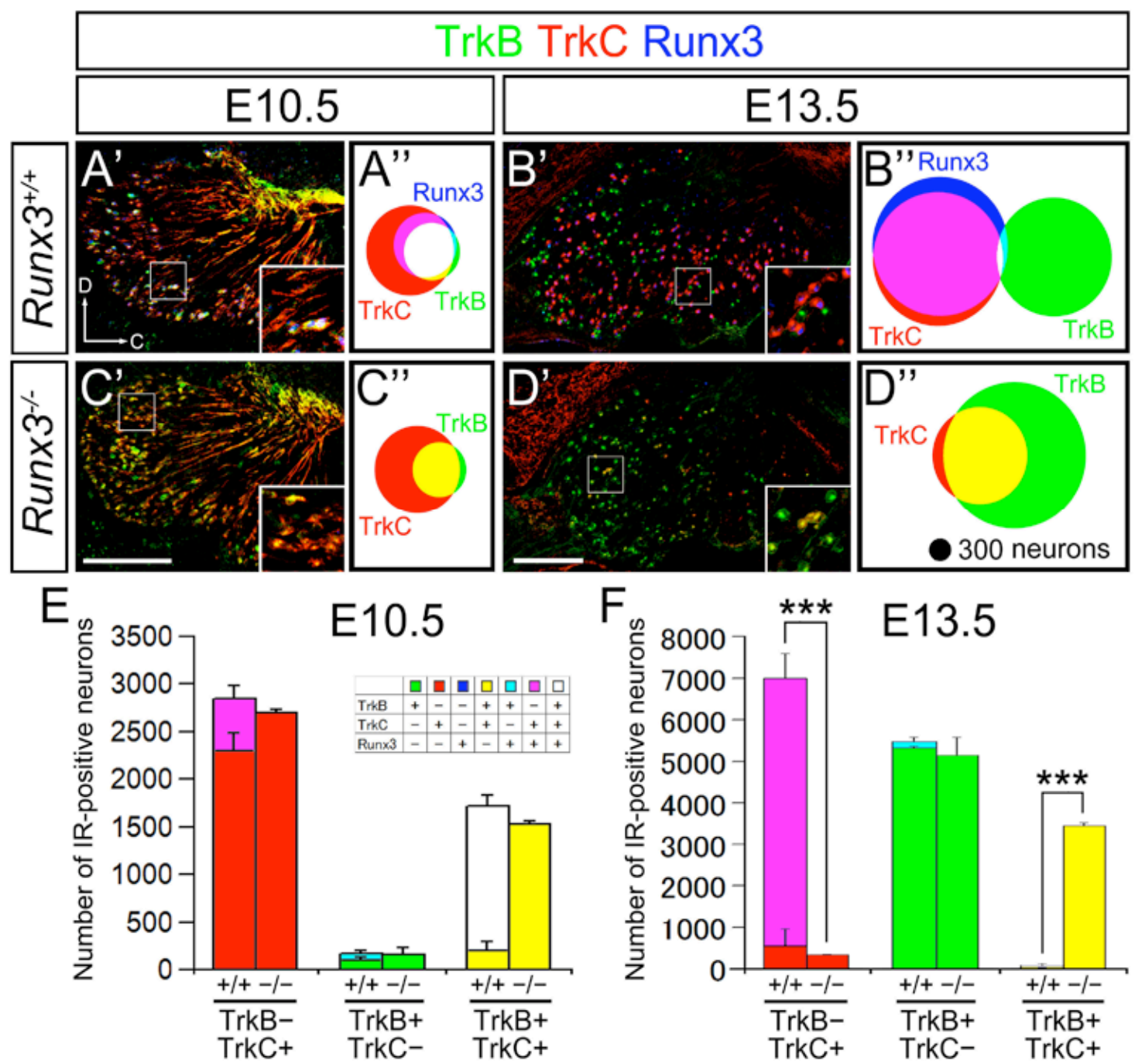
Fig. 5

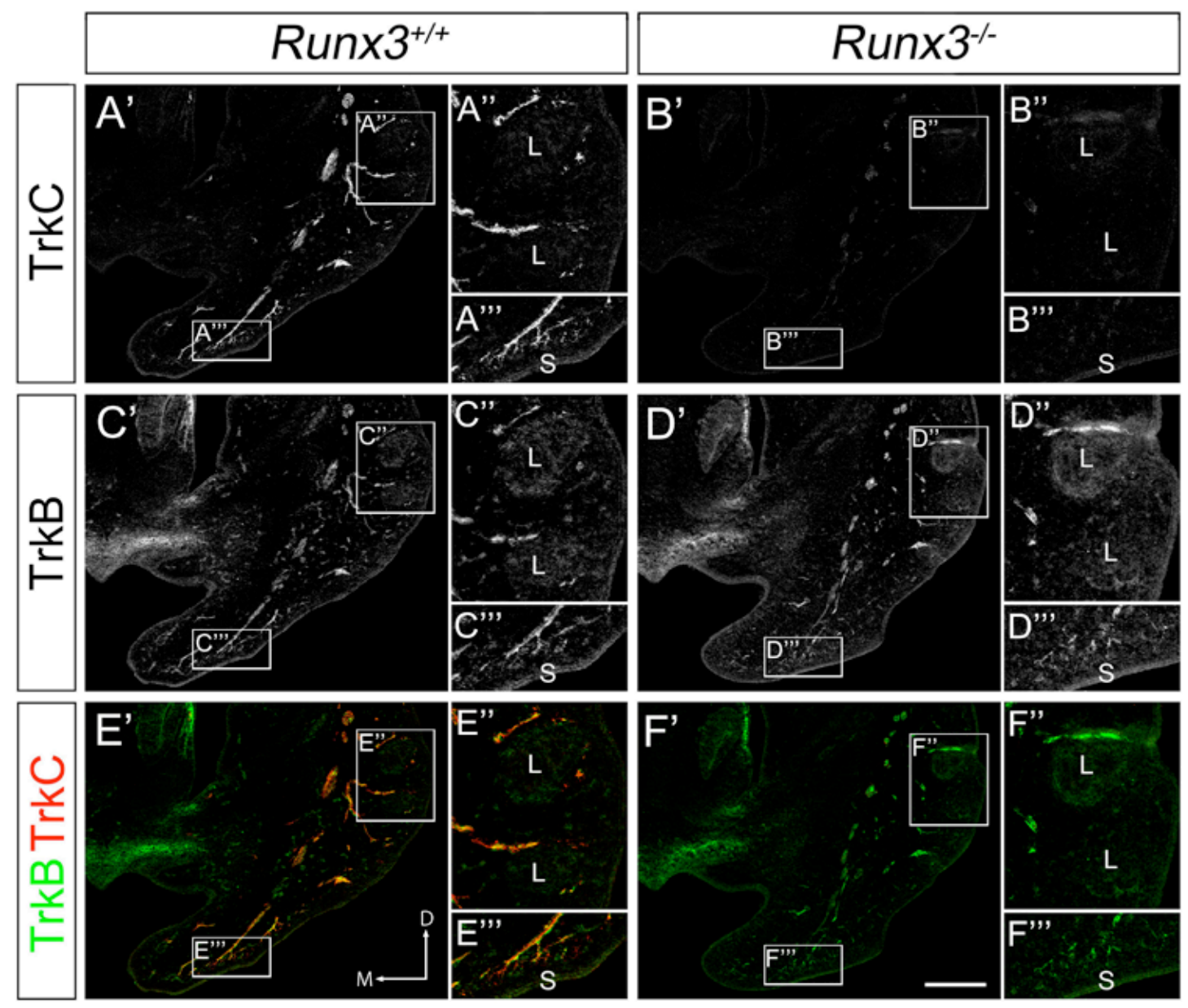


Fig. 6
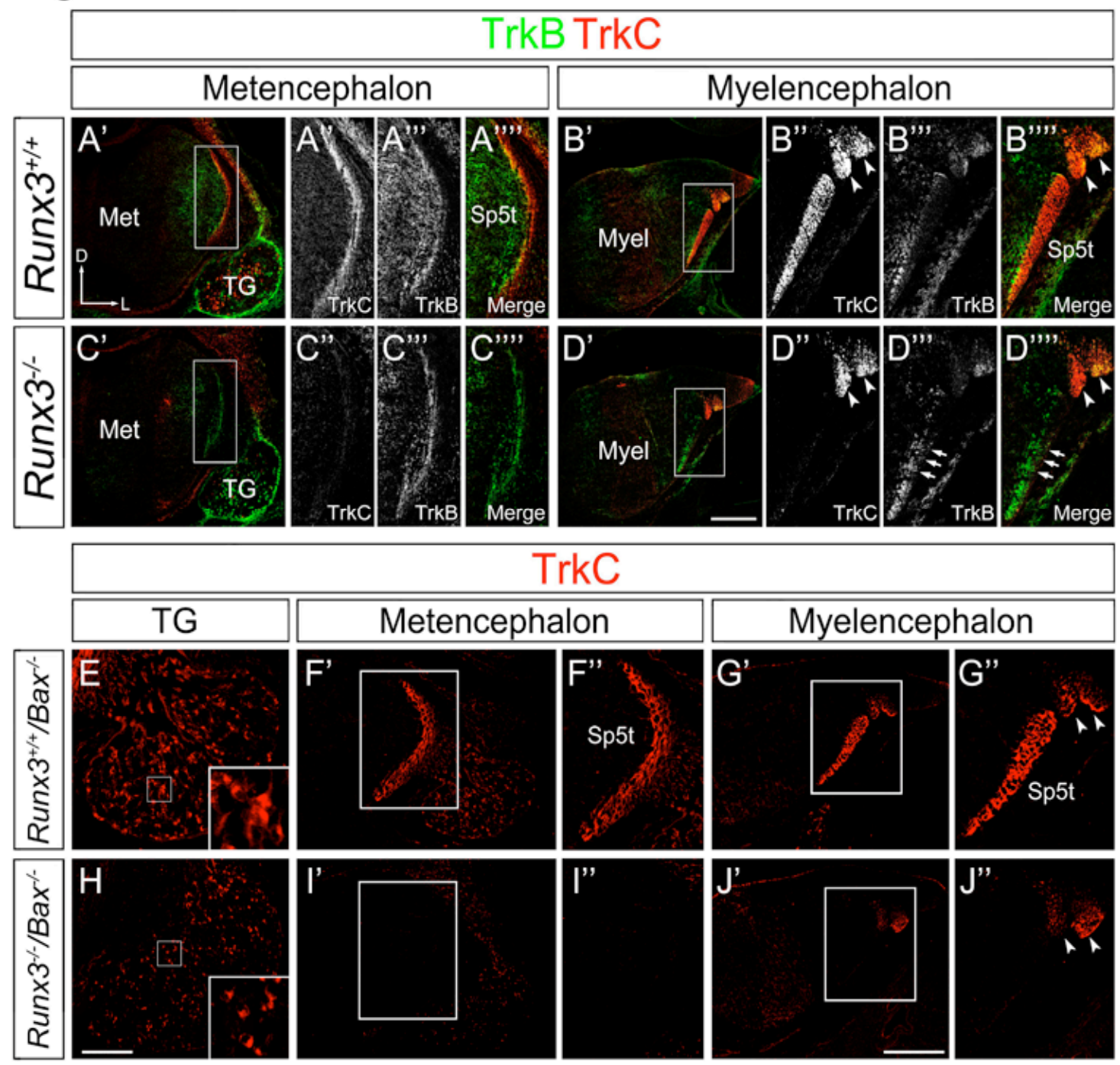
Fig. 7
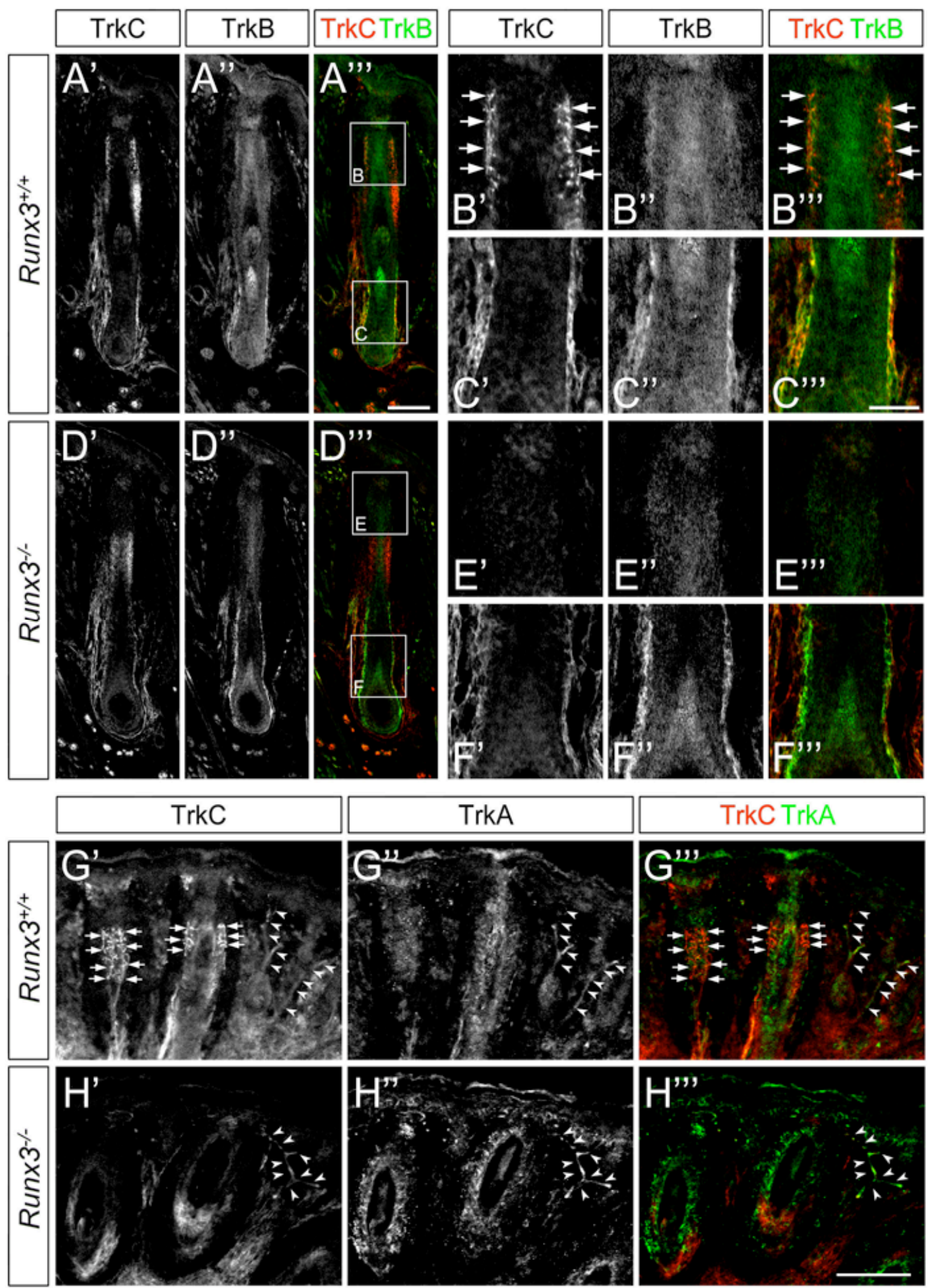
Fig. 8
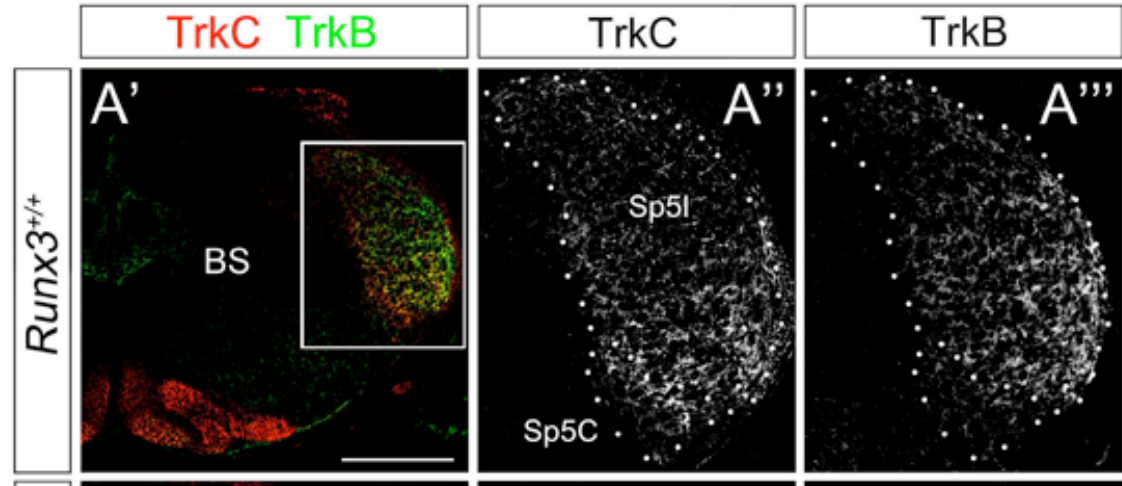

TrkC TrkB
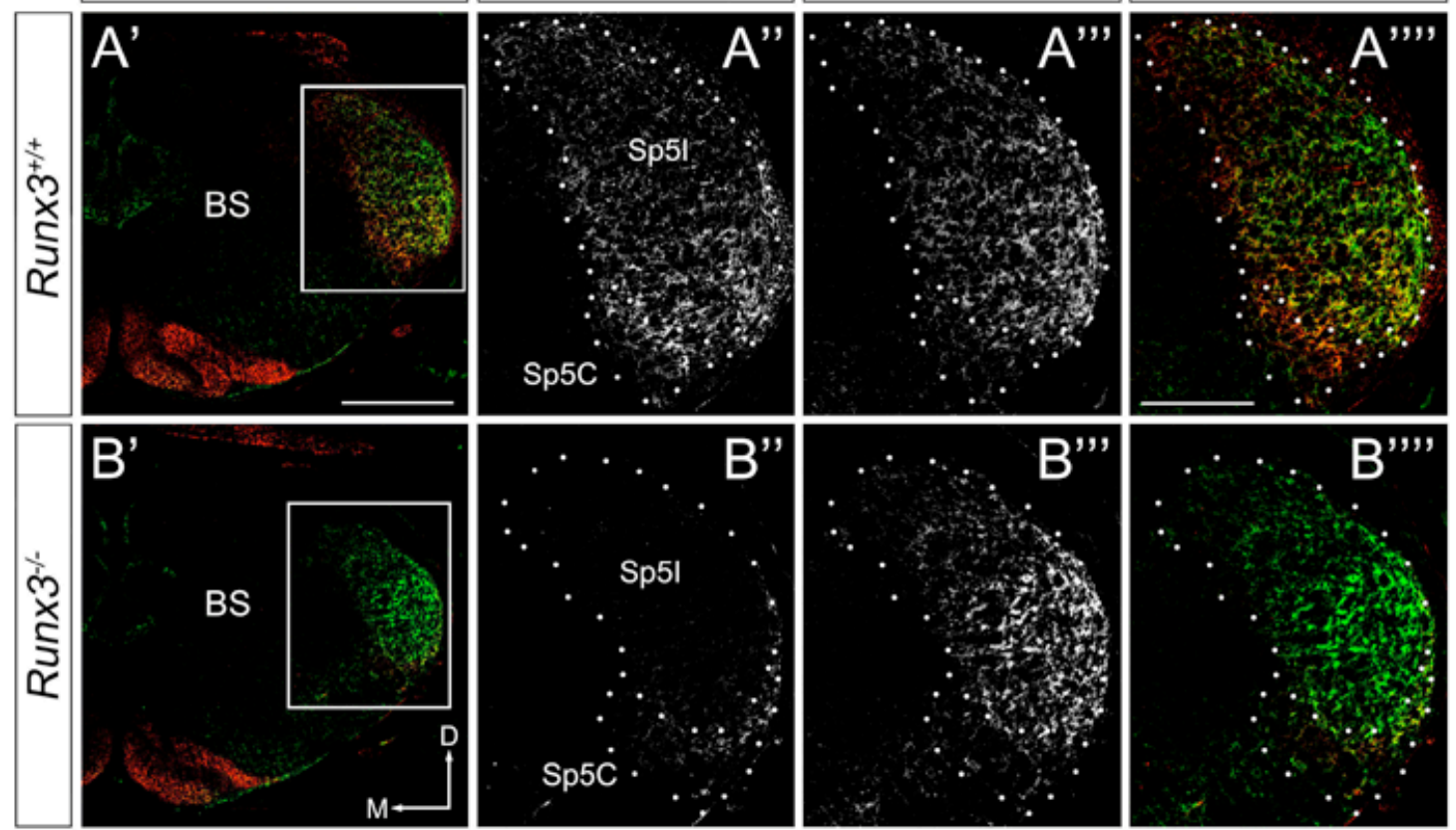


\section{Supplemental materials}

\section{Supplemental figure legends}

Figure S1 Number of TG neuron subtypes in Runx $^{-/-}$mice at P0. (A'-D',A',-D') Immunoreactivity of calretinin (Calr; A',A'), calbindin-D28K (CB; B',B'), calcitonin gene-related peptide (CGRP; C',C'), and substance-P (SubP; D',D') in the horizontal

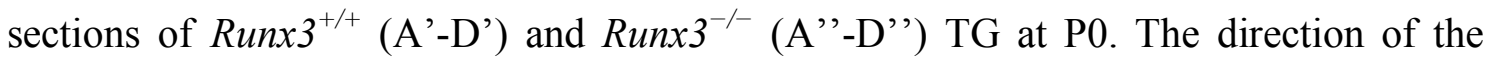
sections are shown in A'. C: caudal, L: lateral. Boxed areas of immunoreactive (IR) neurons are shown at higher magnification in the insets at the bottom right of each panel. (A'"-D"') Quantification of the number of TG neuron subtypes in Runx $3^{+/+}$(white bars) and $\mathrm{Runx}^{-/-}$(black bars) mice. Data are shown as mean \pm SEM. Scale bar: $200 \mu \mathrm{m}$ in D'.

Figure S2 Number of TrkA ${ }^{+}$and NeuN ${ }^{+}$TG neurons in $R u n x 3^{-/-}$mice at E11.5 and E13.5. (A-D) Immunoreactivity of $\operatorname{Trk} A(A, B)$ and $\operatorname{NeuN}(C, D)$ in the sagittal sections of TG of $\operatorname{Runx}^{+/+}(\mathrm{A}, \mathrm{C})$ and $\operatorname{Runx}^{-/-}$(B,D) mice at E11.5 (A'-D') and E13.5 (A'-D',). The direction of the sections are shown in A'. D: dorsal, R: rostral. Boxed areas of immunoreactive (IR) neurons are shown at higher magnification in the insets at the bottom left of each panel. (E,F) Quantification of the number of $\operatorname{TrkA}^{+}$and $\mathrm{NeuN}^{+}$ TG neurons in Runx $3^{+/+}$(white bars) and Run $x 3^{-/-}$(black bars) mice. Data are shown as mean \pm SEM; $* P<0.05$. Scale bars: $200 \mu \mathrm{m}$ in D', $150 \mu \mathrm{m}$ in D'.

Figure S3 No difference in the number of caspase $3^{+}$TG cells between $R u n x 3^{+/+}$and Runx $3^{-/}$mice from E11.5 to P0. (A-D) Immunoreactivity of caspase3 in the sagittal

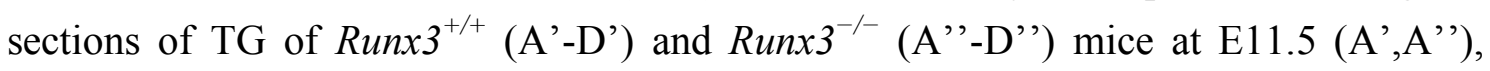
E13.5 (B',B'), E15.5 (C',C',), and P0 (D',D'). The direction of the sections are shown in C'. D: dorsal, R: rostral. Boxed areas of immunoreactive cells are shown at higher magnification in the insets at the bottom left of each panel. (E) Quantitative analysis of the number of caspase $3^{+}$TG cells in Runx $3^{+/+}$(white boxes) and Runx $3^{-/-}$(black boxes) mice. Data are shown as mean \pm SEM. Scale bar: $150 \mu \mathrm{m}$ in A'.

Figure S4 DiI-labeled TG axons in the brainstem of $\operatorname{Runx}^{-/-}$mice. (A-L) Photomicrographs showing DiI-labeled TG axons in the coronal sections of brain stem of $R u n x 3^{+/+}$(A,B,E,F,D,J) and Runx $3^{-/}$mice (C,D,G,H,K,L) at E13.5 (A-D), E16.5 (E-H), and P0 (I-L). The direction of the sections are shown in I. D: dorsal, L: lateral. 
Boxed areas of Dil-labeled axons in E,G,I,K are shown at higher magnification to the right of each panel, respectively (F,H,J,L). DiI-labeling of axons of $R u n \times 3^{-/-}$mice seemed to be less intense than that of $R u n x 3^{+/+}$at each embryonic stage. Met: metencephalon, Myel: myelencephalon, Sp5t: spinal trigeminal tract, Sp5I: the spinal trigeminal nucleus pars interpolaris. Scale bar: $150 \mu \mathrm{m}$ in D.

Figure S5 Runx3 expression in the TG at E13.5. (A) Lateral view of whole-mount lacZ staining of Runx $3^{+-}$mouse. (B) LacZ stained TG in $\mathrm{A}$ is shown at higher magnification. Runx3 was expressed strongly in the maxillary lobe and much more weakly in the ophthalmic and mandibular lobes. TG: trigeminal ganglion, op: ophthalmic lobe, mx: maxillary lobe, md: mandibular lobe. Scale bars: $1 \mathrm{~mm}$ in A, 500 $\mu \mathrm{m}$ in $\mathrm{B}$. 
Fig. S1

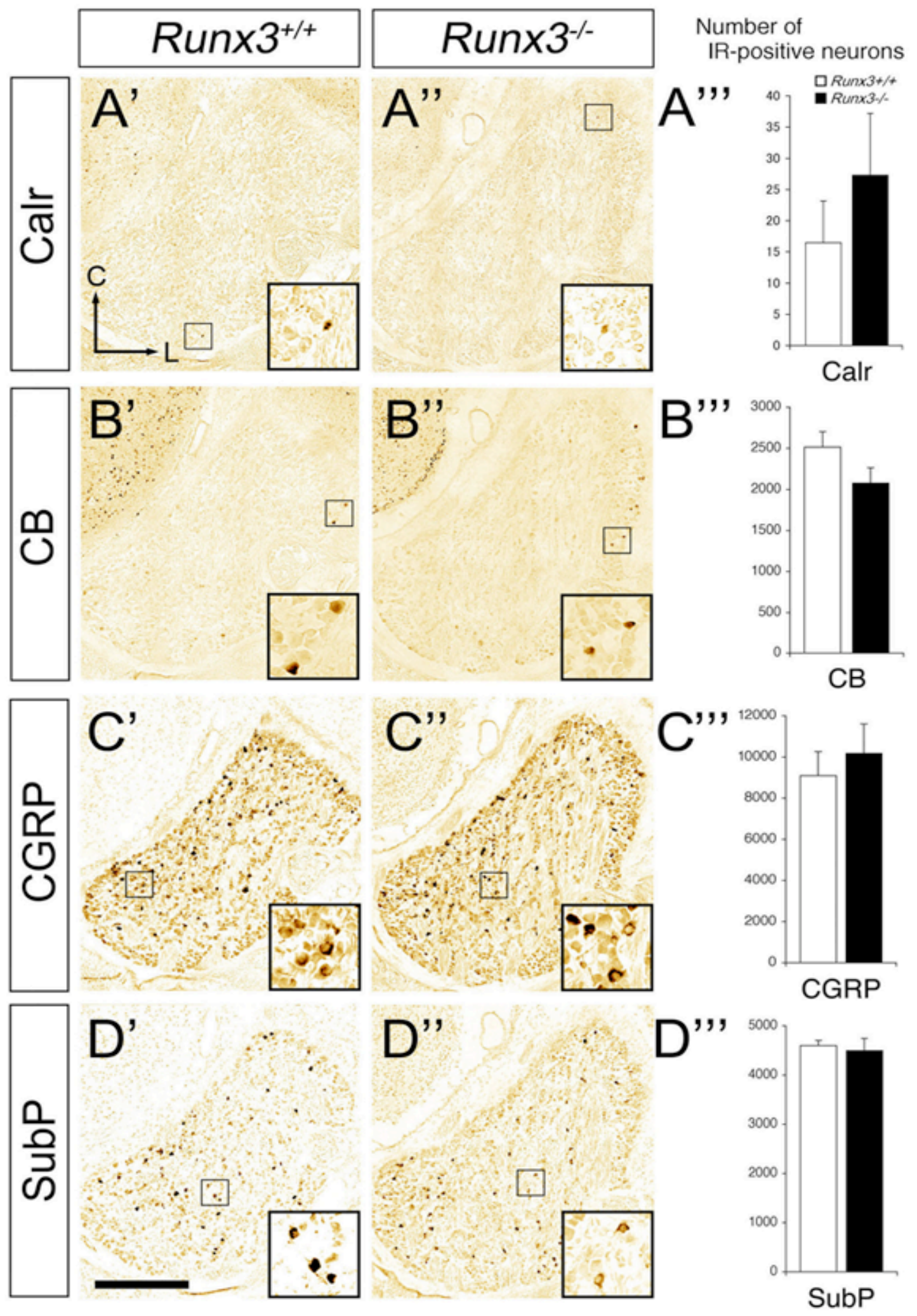


Fig. S2

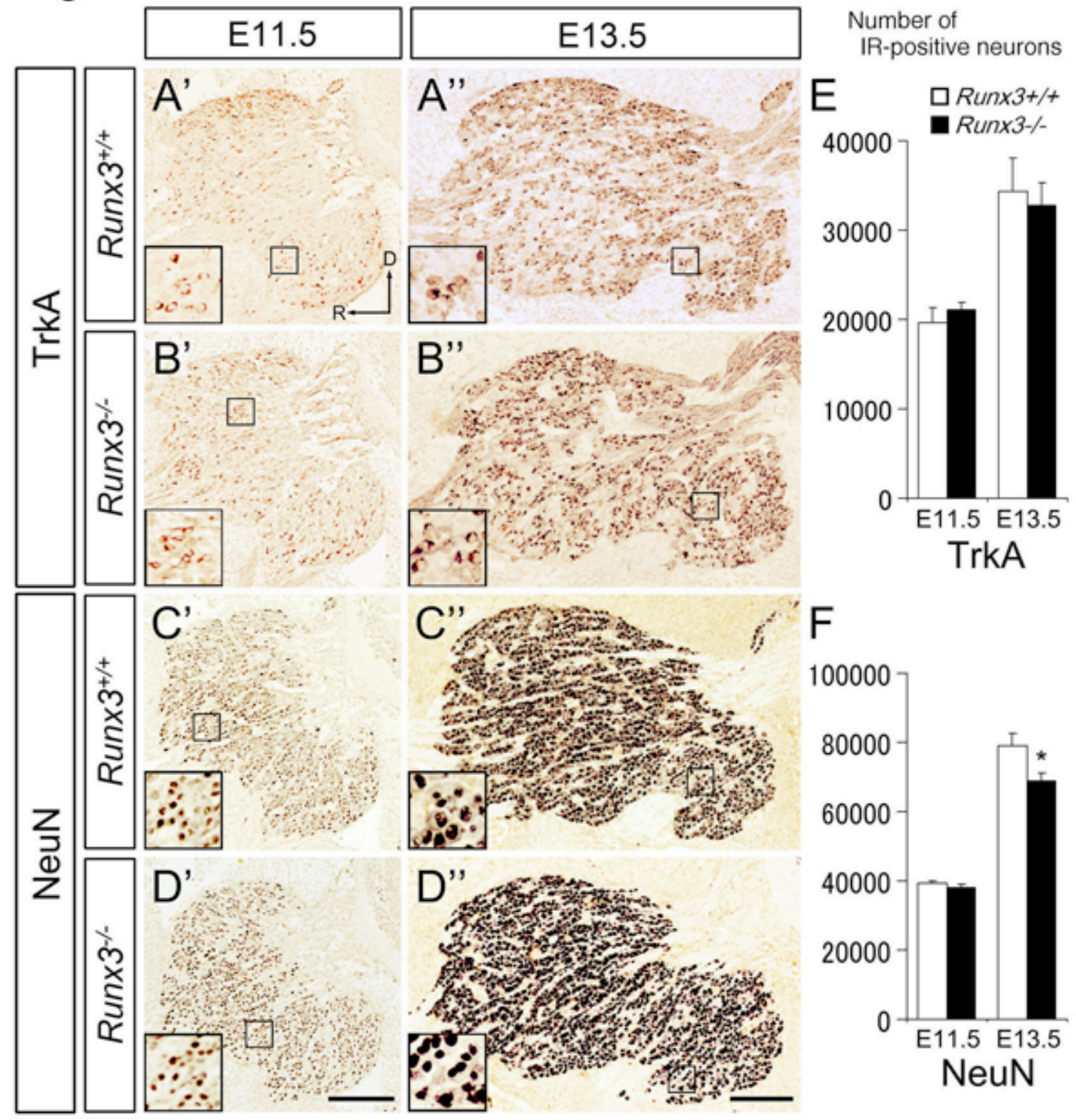


Fig. S3

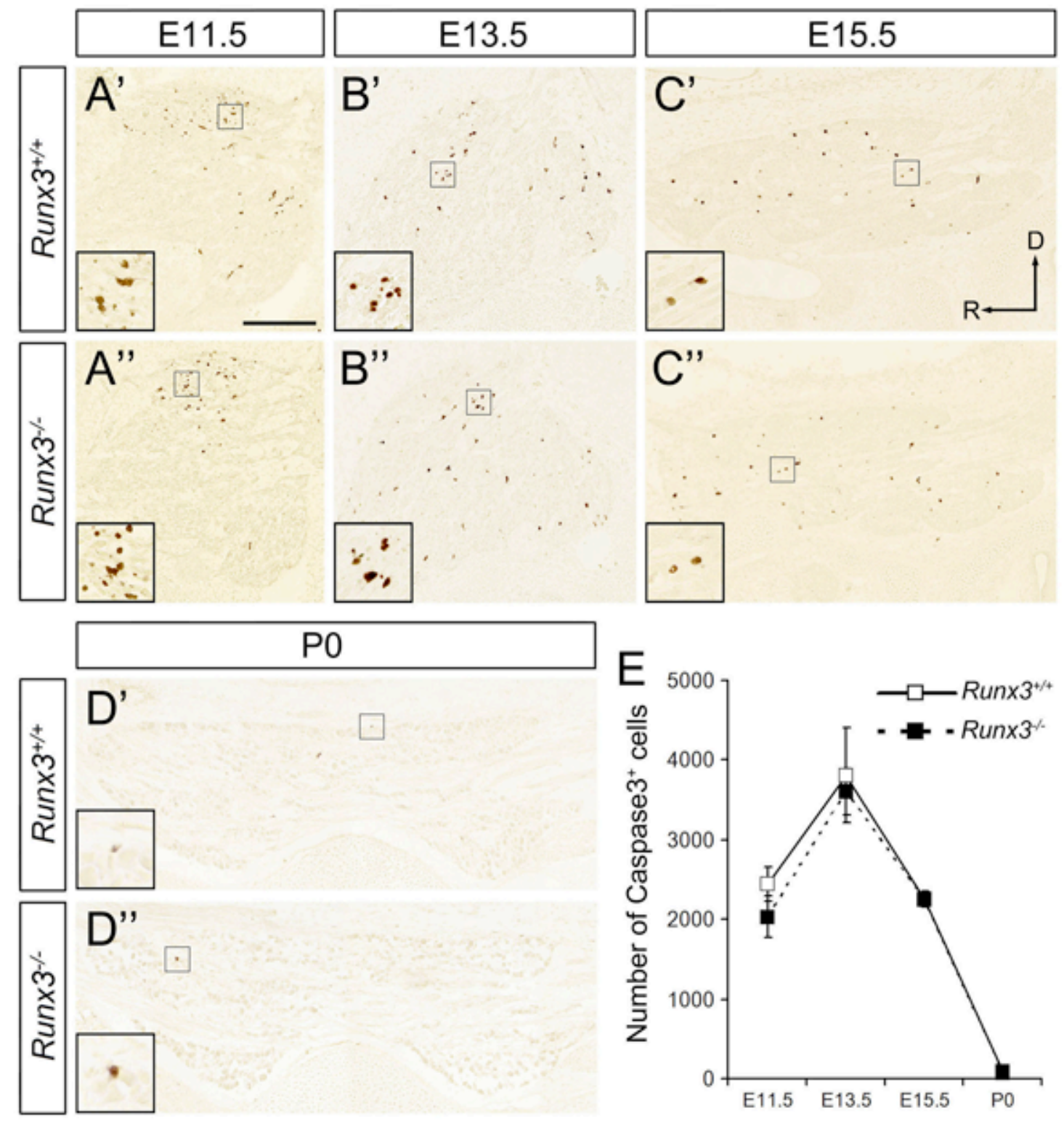


Fig. S4

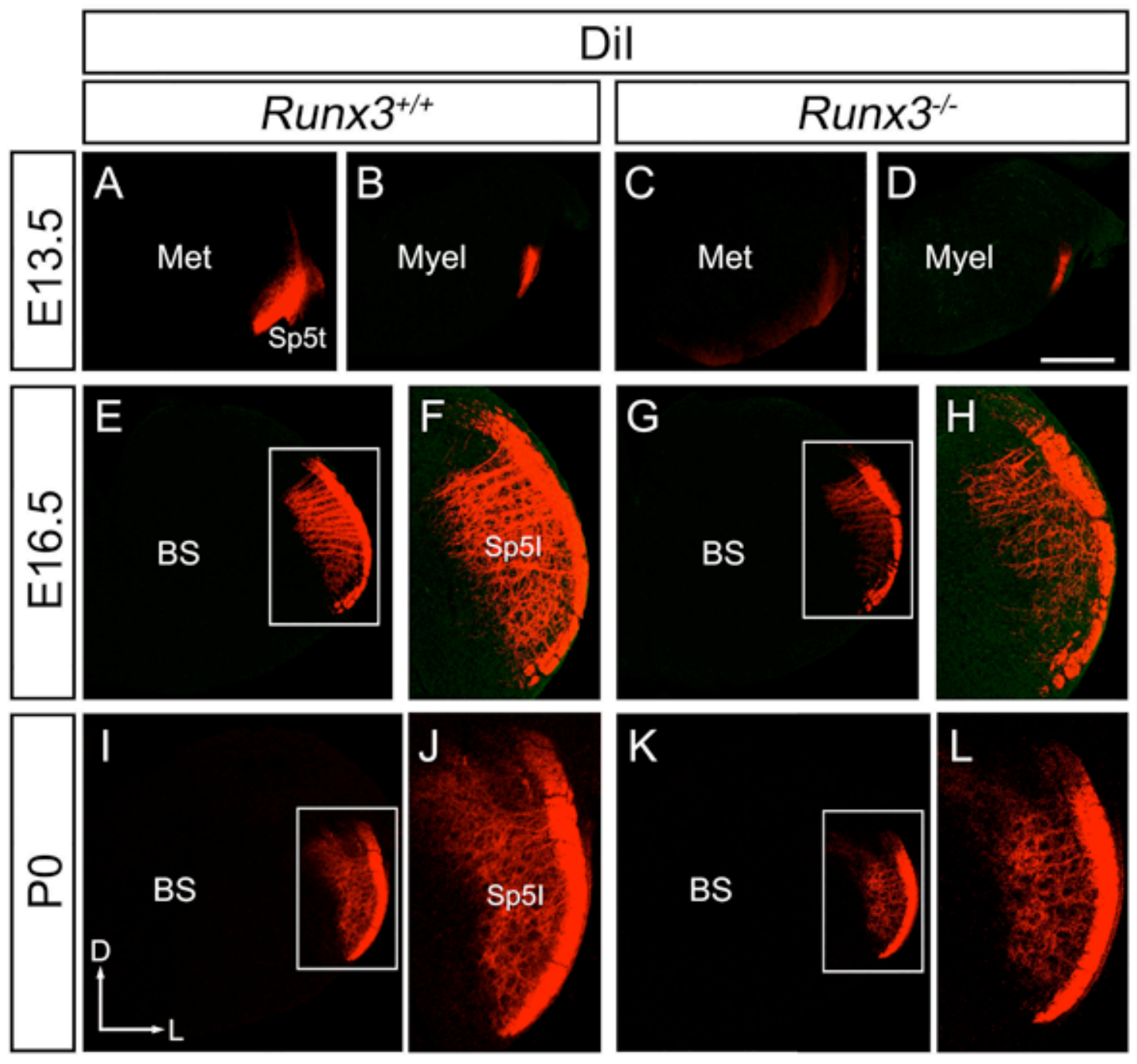

Fig. S5

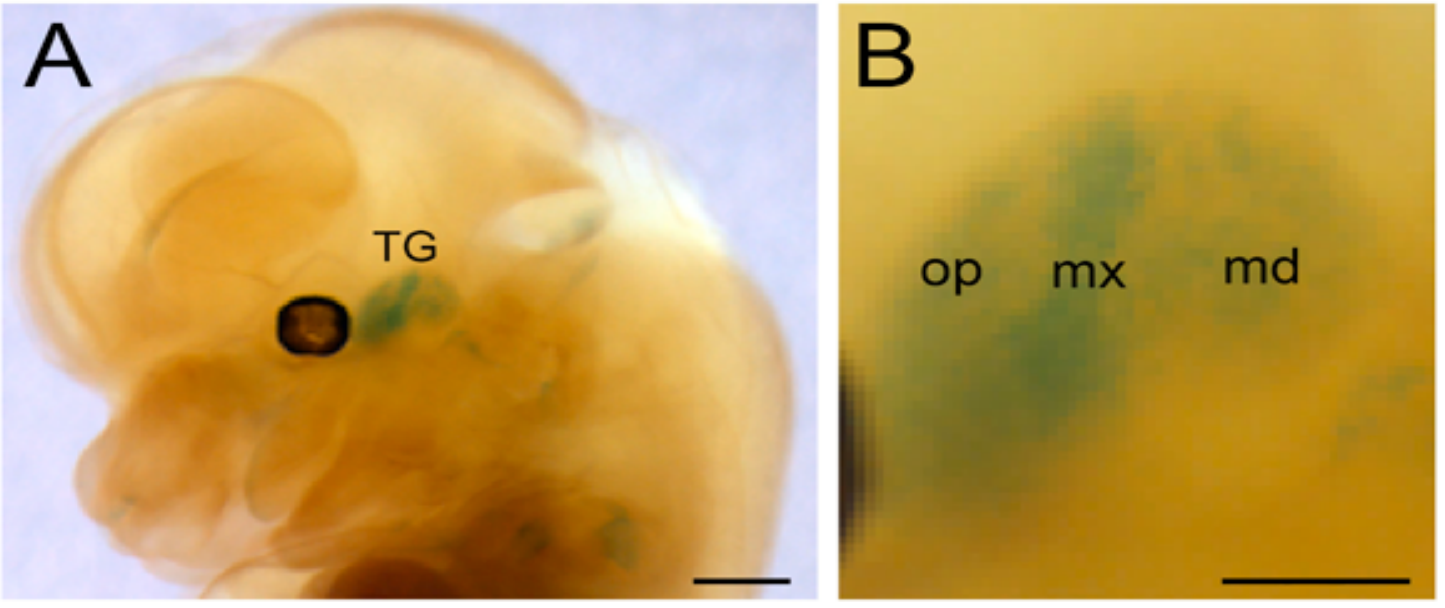

